
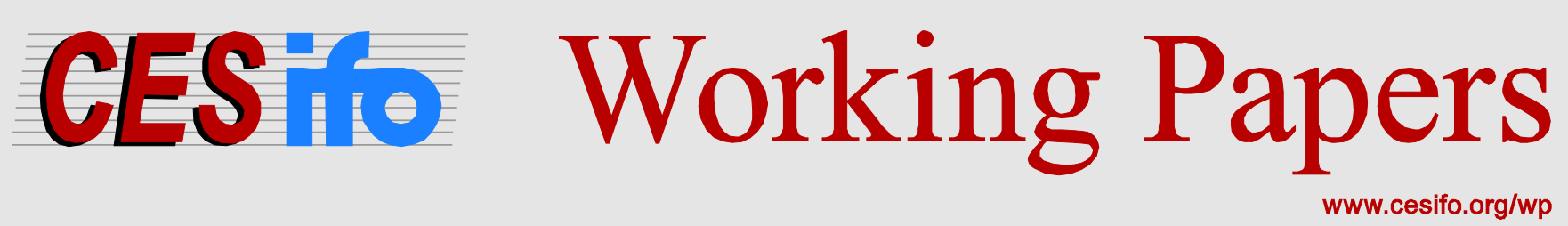

\title{
Liberalizing Russian Gas Markets - An Economic Analysis
}

\author{
Finn Roar Aune \\ Rolf Golombek \\ Hilde Hallre \\ Arild Moe \\ Knut Einar Rosendahl
}

\section{CESIFO WORKING PAPER NO. 5387 \\ CATEGORY 10: ENERGY AND CLIMATE ECONOMICS \\ JUNE 2015}

An electronic version of the paper may be downloaded

- from the SSRN website:

- from the RePEc website:

- from the CESifo website:

www.SSRN.com

www.RePEc.org

www.CESifo-group.org/wp 


\title{
Liberalizing Russian Gas Markets - An Economic Analysis
}

\begin{abstract}
The Russian gas market is highly regulated. In this paper we examine possible impacts of regulatory changes on the demand side of this market. In particular, we consider the effects on Russian energy consumers of removing natural gas subsidies, and how changes in Russian gas consumption may affect its gas export to Europe. We also examine the importance of Russian pipeline capacity to Europe, as well as impacts of hypothetical changes in Russian gas export behavior. For this purpose, we use a detailed numerical model for the energy markets in Europe and Russia - LIBEMOD. Our results suggest that removing implicit subsidies to Russian gas consumers will have substantial impacts on total consumption of gas in Russia, especially in the electricity sector. Gas exports to Europe will be significantly affected as more gas becomes available for exports. Removal of other market imperfections in the Russian energy markets has smaller impacts on prices and quantities than removing gas subsidies. More competitive Russian gas export behavior would lead to much higher gas export to Europe, but our results suggest that Russian welfare would drop due to lower gas export prices.
\end{abstract}

JEL-Code: Q410, Q480, F100, C630.

Keywords: Russian gas prices, Russian gas export, European energy market.

Finn Roar Aune
Statistics Norway
Oslo / Norway
finn.roar.aune@ssb.no

Finn Roar Aune

Oslo / Norway

rinn.roar.aune@ssb.no

\section{Hilde Hallre \\ Frisch Centre \\ Oslo / Norway \\ hhallre@gmail.com}

Arild Moe

Fridtjof Nansen Institute

Lysaker / Norway

arild.moe@fni.no

\author{
Rolf Golombek \\ Frisch Centre \\ Oslo / Norway \\ rolf.golombek@frisch.uio.no
}

\author{
Knut Einar Rosendahl \\ Norwegian University of Life Sciences \\ Ås / Norway \\ knut.einar.rosendahl@umb.no
}

We are grateful for financial support from the Petrosam program of the Research Council of Norway, and for valuable comments at the IAEE-2015 conference in Antalya. 


\section{Introduction}

Russia is the biggest supplier of natural gas to the European market - it is accounting for $25-30 \%$ of total gas use in the European Union. Hence, changes in the highly regulated Russian gas market can potentially have substantial effects on the European gas market. It is therefore of vital interest for European stakeholders to gain knowledge about developments in the Russian gas market, and derived potential impacts on the European market.

In this paper we examine regulatory changes on the demand side of the Russian gas market. This market has been characterized by very low regulated prices to end users, see Section 2 , but over the last 20 years plans to raise domestic gas prices have been announced. For example, in 2007 the Russian government authorized a plan to reach a European netback price - the European price minus costs of transportation and duties between Russia and the European market - by 2011. However, a few years later the plan was postponed to 2018. Other - less ambitious - attempts to raise domestic prices have been more successful: the current Russian price is way higher than 20 years ago. Still, prices are significantly below total (long-run) marginal costs of producing and delivering natural gas. This is considered as a problem by Gazprom - the major Russian gas company - which enjoys a monopoly right to transport and export natural gas in exchange of ensuring secure supply to most domestic consumers at the regulated prices. The future level of domestic Russian gas prices is therefore highly uncertain.

As pointed out in Goldthau (2008) and IEA (2011), higher gas prices in Russia would likely lead to reduced gas consumption among domestic users of natural gas, thereby making more gas available for export, either to the traditional export market in Europe or to emerging Asian markets. In this paper we examine the impact of higher domestic gas prices in Russia, how the derived reduction in domestic consumption may affect Russia's gas export to Europe and the subsequent effects in the European natural gas market. We also look into the effects in the other energy markets in Russia.

In order to study these issues we employ a detailed numerical model of the European and Russian energy markets - LIBEMOD. This model provides a detailed description of a number of energy goods, including natural gas, see Section 3. LIBEMOD endogenizes all main activities in the energy market; investment, extraction, production, trade and consumption of energy, along with a consistent set of equilibrium prices. Demand for energy is modeled separately for five user groups in more than 30 countries. Pipeline and transmission capacities between pair of European countries are endogenously determined. The model is run for a specific future year, here 2020 , and the solution of the model can be interpreted as the long-run static market equilibrium of this year.

LIBEMOD has previously been used to analyze a number of energy-related questions for the European market, for example, price and welfare effects of emission quota allocation rules, see Golombek, Kittelsen and Rosendahl (2013), and the impact of liberalization of different parts of the European energy industry, see Golombek, Brekke and Kittelsen (2013). For this paper the model has been extended to include a detailed modeling of the Russian energy markets, separating this huge country into three regions: West-, Mid- and East-Russia. Because of Russia's large market share in the European natural gas market (25-30\%), we assume that Gazprom is not a price taker but takes into consideration that a higher export quantity will lower the price obtained in the European market. 
In LIBEMOD the description of domestic natural gas markets differ: European natural gas markets are assumed to be competitive, whereas in Russia there are large subsidies to natural gas to mimic the regulated low prices. By lowering these subsidies, we can study the impact of higher domestic Russian gas prices. In particular, by removing the natural gas subsidies the impact of netback pricing is identified.

We make three contributions to the literature. First, we offer a unified, detailed modeling of both the Russian energy markets and the European energy markets, covering activities from extraction to consumption. We are not aware of any other model of the European and Russian energy markets with such details.

Second, we contribute to the small economics literature that applies numerical (equilibrium) models to examine impacts of regulatory changes in the Russian gas market. Sagen and Tsygankova (2008) used a combination of analytical tools and a stylized numerical model to examine the effects of higher gas prices in Russia. They found that higher Russian gas prices may not lead to a substantial increase in export to Europe, partly because increased exports reduce the European gas price, which is not in the interest of Russia. However, because the numerical model in the Sagen and Tsygankova study is quite stylized, for example, there is only one gas user in Europe and one gas user in Russia, and other energy goods are disregarded, our study should be a significant improvement with respect to both modeling tool and calibration strategy.

Finally, our study adds to the literature on Russian export behavior and export capacity between Russia and the EU. Paltsev (2014), employing the global CGE model EPPA, concludes that additional pipeline capacities from Russia to Europe are not needed unless Russia should want to route its gas via other countries than Ukraine and Belarus. However, many of the existing pipelines are old and their capacities may substantially depreciate unless they are upgraded or replaced. In the present paper we study the impact of accelerated pipeline depreciation on the incentives to build new pipeline capacity and on the export volumes from Russia to the EU. We also look into the potential benefits from having a pipe running directly from Russia to Turkey and South Eastern Europe, such as the Turk Stream pipeline announced in the spring of 2015. Furthermore, Russia currently has a gross tax on gas export, which reduces Gazprom's profitability of exporting gas. We examine possible consequences of removing this tax. Lastly, we look into the hypothetical effects of a shift towards competitive Russian gas export, which could be relevant if Gazprom's export monopoly were removed. Similar issues have previously been studied by Tsygankova $(2010,2012)$, using theoretical and stylized numerical models.

There exist several other numerical modeling studies of Russian gas export that are also relevant to our paper. Richter and Holz (2014) use the Global Gas Model (GGM) to assess implications of Russian gas disruptions for EU member states. Hirschhausen et al. (2005) analyze a game between Russia and Ukraine, where Russia decides gas volumes transported through Ukraine to Europe, and Ukraine decides the transit fee. The importance of transit options through Belarus for the outcome of the game is highlighted. Hartley and Medlock (2009) have a global perspective, examining Russia's ability to influence the world natural gas market by simulating their global gas market model RWGTM. Grimsrud et al. (2015) use a stylized dynamic model to investigate how increased shale gas supply may affect current and future market shares of Russia in the European gas market. Other relevant studies of Russian gas export are IEA (2011a, 2014) and Goldthau (2008). 
The rest of the paper is structured as follows. In Section 2 we present features of the Russian gas market - from the breakdown of the Soviet Union to the current situation - in order to understand the main characteristics of the Russian gas industry as well as to assess the politically realistic changes in the years ahead. Sections 3 and 4 give a non-technical description of the energy market model LIBEMOD, and also provides a detailed documentation of data used to calibrate the Russian block of the LIBEMOD model. The modeling results of increased domestic Russian gas prices are presented and discussed in Section 5. Finally, Section 6 summarizes and points at other topics related to the Russian gas industry.

\section{The Russian gas industry}

\section{The heritage from the Soviet period}

The current Russian gas industry is tightly related to the Soviet gas industry structure as it evolved in the 1970s and 1980s. It was characterized by exploitation of huge deposits and long distances between production sites and consumption centers, which required construction of a comprehensive trunk pipeline network. These characteristics lent themselves to economies of scale and - in line with Soviet thinking - a unified industry structure intended to minimize costs of extraction and transportation of natural gas, see Kryukov and Moe (2013).

In the centrally planned economy gas was prioritized in electricity and heat production, thereby making more oil available for highly profitable export. The regulated domestic price of natural gas was very low. Natrul gas was distributed according to priorities in the centrally planned economy. Consumption of various users - power stations, industrial burners and cooking in vast apartment complexes - were usually not measured but estimated according to technical standards of energy needs. The prioritization of natural gas in electricity and heat generation is clearly evident in the consumption structure today; use of gas in the power sector amounts to 40 percent of total gas consumption in Russia.

\section{Gazprom}

In the 1970s and 1980s extraction and transportation of gas were organized within the Soviet Ministry of the Gas Industry. Then in 1989 a new entity, Gazprom, was established. It got control of the entire Soviet unified gas supply system and was also given a regulatory role. This type of agency was something new - an entity outside the ministry structure - although it was state owned.

When the economic reforms in Russia started for real in 1992, an important element was the creation of new industry organizations. Notably this happened in the oil industry where several new companies were formed and subsequently privatized. In the gas sector the situation was different. The top management of Gazprom maintained that the technical characteristics of the gas industry required a centralized organizational structure. These arguments won over reformers who argued that a split-up of the production side was desirable. In 1992, Gazprom was transformed into a jointstock company, which was subsequently partly privatized. ${ }^{1}$ The state, even if it had a minority stake of some 40 percent, retained key control, but generally the company became independent.

\footnotetext{
${ }^{1}$ Entities located outside Russia, that is, in other former Soviet republics, were of course no longer part of Gazprom after the dissolution of the Soviet Union.
} 
The new company obtained ownership of all the major physical assets of the Russian gas industry for free. In addition, the functions of the new company were extended to include roles which had earlier been covered by bodies outside the industry: investment and output targets, which had previously been decided by central planning organs, now became part of the internal processes in Gazprom. Distribution to final consumers, which used to be the remit of a separate structure, now became a business activity of Gazprom. Gas exports, which earlier were managed by a special foreign trade organization outside the gas industry, now became part of the activities of the company. In the end, the gas industry became more centralized and monopolized than it had been in the Soviet system.

Gazprom did not only get new privileges, it also inherited old obligations. It was expected to continue to supply gas domestically at very low prices, but in exchange the company was allowed to keep a considerable share of the export revenues. Thus a situation emerged were domestic supplies became almost a secondary activity compared to exports, where the big money was earned. Domestic supplies were, however, in volume terms about four times higher than exports to Europe. This arrangement can only be understood in the context of the serious economic crisis and restructuring taking place in the 1990s. Maintaining stable gas supplies was of paramount importance for social stability, and low gas and electricity prices were important instruments to ensure this goal. Gas continued to be distributed like in the centrally planned economy: consumers had to obtain permission to take gas in certain volumes, and new consumers could not freely choose energy sources. Gas was, more than other fuels, a subsidized commodity and was de facto rationed.

\section{Netback pricing}

Starting rather early in the 1990s, gas prices were in fact increased - but from a very low level. By 1996 the average official gas price was around 250 roubles per $1000 \mathrm{~m} 3$ (corresponding roughly to 45 USD). But with a deep economic crisis most of Gazprom's customers were not able to pay the increasing bills. Many turned to surrogates for payment: goods, shares in enterprises and various services. Others did not pay at all. Gazprom reported that in 1998 their domestic consumers paid for 28.5 percent of the gas deliveries only, see Gazprom (1998). According to OECD (2002, p. 128), only 16 percent of these deliveries were paid in cash.

This was the nadir of Gazprom. Then the situation improved: After the economic crisis in 1998 and subsequent rouble devaluation, both Russian exports and the general economy picked up. Gazprom was now allowed to take tougher measures against non-paying customers, and cash payment was widely enforced in the state sector. The company's take-over of local distribution organizations also helped increasing the share of paying customers. By 2000, 62 percent of the delivered gas was paid for, see $\operatorname{OECD}(2002$, p. 125), and by 2004 Gazprom reported that 98 percent of the domestic deliveries were paid in cash, see OECD (2004). This development also reflects that gas prices had been allowed to fall in real terms: by 2000 gas prices were 62 percent below the 1996 level, see $\operatorname{OECD}(2002$, p. 125).

In the transition from the centrally planned economy to a market oriented system, Gazprom had been given production infrastructure and pipelines that had been built and financed by the Soviet state (see discussion above). Thus Gazprom had very low capital costs and the company could therefore handle losses in the domestic market as long as it kept the export income. But as years went by the need for renewal of the pipeline network as well as investment in production capacity grew. Gazprom therefore started paying more attention to the domestic market, first by devising 
schemes for payment when cash was lacking, and then, as the general economic crisis subsided in the early 2000s, to argue for domestic price increases: prices should cover operating costs and also allow for accumulation of investment funds. Gazprom's argumentation was helped by Russia's negotiations to become a WTO member: the Russian government committed to reduce subsidies to domestic customers and raise gas prices to USD $37-42$ per $1000 \mathrm{~m} 3$ by 2006, and further to USD 4957 by 2010 , see $\operatorname{OECD}(2006, \text { p. } 43)^{2}$

Despite the decision to increase the price of gas from 2000, by the end of 2003 the regulated average gas price for industry customers was still low: it corresponded to USD 24 per 1000 m3, see OECD (2004), page 43. A plan for raising the regulated gas price to European netback parity - European price minus the extra transportation costs and duties on export - was authorized by the Russian government in May 2007, see Russian government (2007a); this plan addressed both the concerns of the WTO and Gazprom's request. The government foresaw a stepwise increase whereby the domestic price for industry would reach European netback parity by 2011.

In 2007, experts considered the plan as feasible even though the price for industrial consumers corresponded to USD 44 per $1000 \mathrm{~m} 3$-the netback price would have been USD 145 per $1000 \mathrm{m3}$, see Tsygankova (2008). However, the international oil price increases in the following years implied that the target gas price was steadily increasing because the export gas price was linked to oil. In 2013, the netback price would have been USD 230 per 1000 m3, see Henderson and Pirani (2014, p. 122 ), a price level that would have had a detrimental impact on most Russian consumers. In the end the government therefore postponed the netback goal, first to 2014 and later to 2018.

\section{The recent gas price plan}

By 2013 the regulated price had reached USD 105 per 1000 m3, see IEA (2014, p. 107). Still, according to Gazprom (2013) this was not enough to cover investments needed to sustain production in the long run. Gazprom continued to argue that a European netback price should be the goal in order to secure the viability of the gas industry as well as enhance economic efficiency: "undervalued prices negatively affect the domestic economy, because there is no favorable environment for promoting gas- and energy-savings as well as for developing high-tech industries", see Gazprom (2013). For some years the government's policy was more or less in line with Gazprom's wishes: in 2010 the government decided to increase gas prices by 15 percent annually until 2015.

There was, however, growing concerns that higher domestic gas prices would weaken the competitive position of the manufacturing industry and hamper economic growth. These concerns were enhanced by the significant fall in gas prices in the United States because of the shale gas revolution. ${ }^{3}$ In the end the policy was adjusted: in the fall of 2013 the government decided to freeze gas prices until (July) 2015, then index the price to inflation, and after 2016 let gas prices grow slowly, see Table 1. According to this plan, gas prices to industry users may on average increase by 3.2 percent annually between 2016 and 2030, see Vedomosti (2013). This is supposed to result in a domestic industry gas price slightly above 70 percent of the netback price by 2030 . For households, the plan is to increase prices at a rate slightly higher than the one for industry -3.5 percent.

\footnotetext{
${ }^{2}$ According to the Russia-European Union bilateral agreement on Russia's WTO accession, Russian was allowed to keep a dual price system with different prices for exports and the domestic market, but the goal should be to raise the domestic price to the long-run marginal cost, see Rungi, A. (2012).

${ }^{3}$ O. Deripaska in meeting between President Putin and Russian business leaders, 23 May, 2013. http://kremlin.ru/news/18172
} 
Table 1. Ministry of Economic Development's gas price development plan. Annual growth rates

\begin{tabular}{l|cccc}
\hline & $2016-2020$ & $2021-2025$ & $2026-2030$ & $2016-30$ \\
\hline Industry price & 4.4 & 2.9 & 2.1 & 3.2 \\
Household price & 4.5 & 3.5 & 2.6 & 3.5 \\
\hline
\end{tabular}

Source: Vedomosti (2013).

To sum up, after the establishment of Gazprom in 1989 the gas industry first became more centralized and monopolized than it had been in the Soviet system. Since 1990, prices of gas have increased considerably but they are still far below the netback price. Whereas Gazprom for years has been pushing for a higher price, the most recent plan for domestic Russian gas prices indicates only a moderate increase in prices. We believe, however, that the inherent uncertainties in the Russian gas market justify exploring impacts of alternative Russian gas prices. In the present paper we therefore study effects of Russian gas prices being increased up to netback parity.

\section{Increased domestic competition}

By law, Gazprom only held a monopoly on exports and long-distance transmission. Production was open also for other companies, but obviously they would need an arrangement with Gazprom to sell their gas. Other gas producers had emerged already in the 1990s, and by giving these access to the domestic market, pressure was taken off from Gazprom to increase domestic supply.

Since 2007 non-Gazprom producers had been allowed to sell their gas at negotiated prices that could be well above the regulated Gazprom price. Further, Gazprom had been granted the right to sell gas at a premium price to new customers and also to charge this price for sale of additional gas to old customers, that is, deliveries of gas above their pre-specified quotas, see Russian government (2007b). However, as the regulated price increased, the domestic market became commercially more interesting; according to Gazprom (2013), by 2009 the domestic price of gas exceeded operating costs. The non-Gazprom producers found that they could sell gas at a lower price than Gazprom's regulated price and still make a profit. Consequently they started to compete for market shares by lowering the price - Gazprom was obliged to sell most of its gas at the regulated price.

By 2012, about one third of Russian consumption was covered by non-Gazprom producers, see Henderson and Pirani (2014, p.117). This development reflected that i) many industrial consumers had been able to purchase non-Gazprom gas at a more favorable price than the regulated price, and ii) non-Gazprom producers had access to the trunk pipeline system owned and operated by Gazprom, and these services had become more reliable. To stave off the increasingly aggressive competition, Gazprom now wanted to sell gas below the regulated price, and in September 2014 the Federal Tariff Service drafted a decree that would allow a 15 percent discount to large consumers, see Interfax Russia \& CIS Oil and Gas Weekly (2014).

The recent changes in market structure may reflect a weakened political position of Gazprom and increased political support for other producers, especially Novatek and Rosneft. In fact, over time the "social contract", which provided Gazprom with much of its export revenues against an obligation to serve the domestic market at very low gas prices, may become outdated: other gas producers, which over the last years have increased their domestic market share, may challenge Gazprom's export 
monopoly (a part liberalization of LNG exports was decided in 2013). These observations justify to study the implications of a competitive Russian gas industry as well as a liberalization of Russian gas export.

\section{The numerical model LIBEMOD}

To study effects of higher Russian gas prices we use LIBEMOD, a multi-good equilibrium model of the European energy markets. It covers 31 countries, including a recently developed special block for Russia. The model focuses on decisions taken by investors, producers, traders and consumers, thereby truly endogenizing energy investments in production capacities and international transmission capacities, extraction of fossil fuels, production of electricity, trade in energy between countries and consumption of energy. The model specifies eight energy goods; three types of coal (coking coal, steam coal, lignite), natural gas, oil, two types of bioenergy (biomass, biofuel) and electricity. These quantities are determined simultaneously with the market-clearing prices of all energy goods as well as the market-clearing prices of transmission services.

Whereas there are European markets for natural gas, biomass and electricity in LIBEMOD - these goods are traded between pairs of countries under the restriction that trade cannot exceed the transmission capacity - coal, oil and biofuel are traded in global markets. Each country is represented by a node, and within each country there is transport of all types of energy to all types of users of energy (households, services, industry, transportation and electricity generation), modelled by a constant unit cost that differs between energy users and energy goods. Whereas demand from each group of end users is derived from a nested CES utility function, demand from electricity generation follows from the optimization problem of an electricity supplier.

In LIBEMOD there is a number of electricity technologies available for supply; four types of fossil-fuel based electricity (steam coal, lignite, natural gas, oil), three types of hydro (reservoir, run-of-river, pumped storage), biomass power, wind power and solar. The model makes a distinction between power stations that were available in the data year of the model (2009) - these have pre-determined capacities that cannot be expanded - and power stations coming online after 2009 because of investments.

The electricity efficiency of a pre-existing plant differs among type of technologies and plants. In contrast, for new fuel-based generation capacity electricity efficiency differs only among type of technologies. For renewable electricity technologies, cost of investment (euro/kW) differs between technologies and the annualized cost of production (euro per kWh) differs between technologies, countries and also within a country. This reflects that sites differ; the number of annual wind hours, for example, differs both within a country and between countries.

In LIBEMOD, each generator maximizes profits with respect to how much of the installed capacity to maintain, how much electricity to produce in each time period and how much to invest in production capacity subject to a number of technology restrictions; some of these are common to all technologies, whereas others are technology specific. Income is generated from selling electricity and selling available maintained capacity to a reserve capacity market (the latter is not an option for intermittent power). Power supply is associated with a number of cost elements, reflecting cost of inputs, cost of maintaining the production capacity, start-up costs as well as cost of investment (the latter applies to new generation only). Electricity can be traded between pairs of countries subject to 
the corresponding international transmission capacity, which can be expanded if such investments are profitable (the same is the case for international gas pipes). For more modeling details, data and the calibration strategy of LIBEMOD, see Aune et al. (2008) and the LIBEMOD website. ${ }^{4}$ LIBEMOD is available in various versions. ${ }^{5}$ In the present study we use the long-run deterministic LIBEMOD. For all countries expect Russia, we assume competitive markets.

The Russian model block differs from the modeling of the other European countries along some dimensions. First, Russia is the largest country in the world. Whereas a major share of its population lives in the Western part of the country, most of its natural gas reserves are found in the northern part of Siberia. In addition, there are reserves in the eastern parts of Siberia and in the Far East. Currently, these latter gas reserves are used primarily for LNG export, but may have the potential for export to China through pipes. To allow a detailed modeling of Russia, in particular to examine how extraction of gas in one part of Russia may have impact on consumption of gas in other parts of the country as well as on exports to Europe, we have divided Russia into three auxiliary units; West-, Mid- and East-Russia. Each of these is modelled as a separate country with respect to investment, extraction, production, trade and consumption of energy.

Second, because Russia is the major exporter of natural gas to Europe, and Gazprom has exclusive rights to export Russian gas to Europe, we assume that Russia (through Gazprom) exercises market power in the European natural gas market. This is in contrast to the modelling of the other countries, where we assume competitive arbitrage traders (which we also assume within the Russian market). However, we also simulate a scenario with competitive Russian gas export.

Third, investment in pipes from Russia to Europe has been characterized by a mix of concerns like the ability of Russia to control the pipes and the business interests of Gazprom. These factors have led to an aggregate capacity exceeding the one needed to serve present export contracts, see discussion in Section 2. On the other hand, much of the existing pipeline capacity is old and may depreciate more rapidly than other pipeline capacity. We therefore simulate alternative (future) scenarios for depreciation of Russian pipeline capacity and pipeline investments.

Domestic Russian gas prices, in particular to households, have been far below their corresponding social costs, see Section 2 . We take this fact into account by introducing a subsidy that reflects the difference between the (estimated) social cost of delivering natural gas to a group of gas users (in one of the three auxiliary Russian countries) and the corresponding (partly observed, partly estimated) user price of natural gas. We model a liberalization of the domestic natural gas markets in Russia as a reduction in these subsidies. In particular, by removing these subsidies we simulate the effects of introducing competitive natural gas markets in Russia.

\section{Data and calibration}

Calibration of LIBEMOD requires a wide set of data and parameters. For the 30 European model countries as well as Russia, the LIBEMOD website provides a detailed data documentation. Below we

\footnotetext{
${ }^{4}$ http://www.frisch.uio.no/ressurser/LIBEMOD

${ }^{5}$ The LIBEMOD versions differ with respect to time horizon - short run (pre-determined capacities) vs. long run (endogenous capacities), market structure (competitive markets vs. imperfect competition), and whether decisions are taken under uncertainty or full information.
} 
focus on the main data sources used to calibrate the model for Russia. Some more details are presented in the Appendix.

Russia consists of 83 federal regions - in 2000 these were grouped into seven official federal districts. In the LIBEMOD model we introduce three auxiliary countries RU1, RU2 and RU3; these are aggregates of the seven official Russian districts. RU1 covers the Central Federal District, Volga Federal District, Northern Caucasus Federal District, North Western Federal District and Southern Federal District. RU2 corresponds to Ural Federal District, whereas RU3 covers Siberia and the Far Eastern Federal District, see Figure 1.

Figure 1. Consumption nodes and natural gas production nodes in Russia

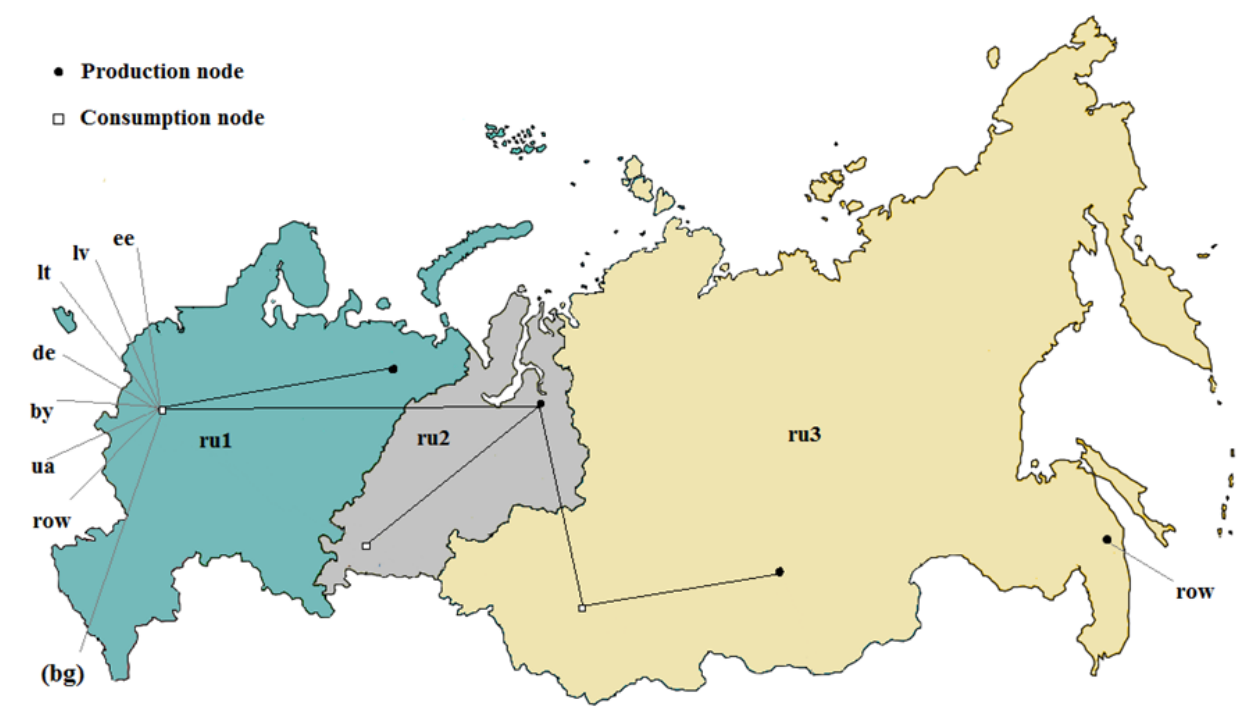

Note: The consumption nodes are marked in grey and labelled RU1, RU2 and RU3, and the natural gas production nodes are marked in black.

\section{Supply of energy}

IEA Extended Energy Balances (IEA 2011b) has been used as the main source for total Russian production of coal, natural gas, oil, biomass, biofuels and electricity. Several sources have been used to make a complete regional dataset for RU1-3, see discussion in the Appendix. Table 2 shows the final result. 
Table 2. Production in the Russian regions in 2009. Mtoe

\begin{tabular}{ccccc}
\hline & RU1 & RU2 & RU3 & Total \\
\hline Natural gas & 25.5 & 421.1 & 18.5 & $\mathbf{4 6 5 . 1}$ \\
Steam coal & 5.1 & 0.6 & 82.2 & $\mathbf{8 7 . 9}$ \\
Coking coal & 2.3 & 0.3 & 38.1 & $\mathbf{4 0 . 7}$ \\
Lignite & 1.4 & 0.2 & 23.2 & $\mathbf{2 4 . 8}$ \\
Oil & 146.5 & 310.6 & 36.2 & $\mathbf{4 9 3 . 3}$ \\
Biofuel & - & - & - & - \\
Biomass & 2.2 & 0.3 & 0.5 & $\mathbf{3 . 0}$ \\
\hline
\end{tabular}

\section{Consumption of energy}

The IEA Extended World Energy Balances database, see IEA (2011b), has a full set of consumption data for Russia, but due to the regional structure in the model additional data sources and own assumptions have been used to complete the dataset. A comprehensive data source for energy consumption on a federal district level for Russia has not been identified and information regarding sectorial consumption is generally hard to find. The sources are mainly Russian, and vary between energy goods. Below is an outline of the data sources and assumptions for each of the energy goods included in the model. To ensure consistency within the model, the energy balance from IEA Extended Energy Balances has been used as the total for Russia (the sum of RU1, RU2 and RU3).

Pirani (2011) provides regional and sectorial data for natural gas consumption in Russia in 2004. It has not been possible to locate the same data for the base year (2009) so it is assumed that the same distribution across regions and sectors applied in 2009. This information was then used to allocate the IEA national quantities for 2009 to the three regions. For the gas used in power production actual data for 2009 from APBE (2010a) has been used.

Table 3. Consumption of natural gas by Russian region in 2009. Mtoe

\begin{tabular}{ccccccc}
\hline Region & Households & Industry & Transport & $\begin{array}{c}\text { Electricity } \\
\text { producers }\end{array}$ & Services & Total \\
\hline RU1 & 39.8 & 41.1 & 147.7 & 2.2 & $\mathbf{2 3 0 . 8}$ \\
RU2 & 1.5 & 12.5 & 45.5 & 0.3 & $\mathbf{5 9 . 9}$ \\
RU3 & 0.3 & 7.1 & 11.0 & 0.1 & $\mathbf{1 8 . 5}$ \\
\hline
\end{tabular}

\section{Natural gas trade}

ENTSOG (http://www.entsog.eu/maps/transmission-capacity-map) and EEGA (East European Gas Analysis, see http://www.eegas.com/fsu.htm) have capacities for the export pipelines that run from Russia into Europe, see Figure A1 in the Appendix. The largest Russian natural gas fields that are currently connected by pipeline are located in the Yamal-Nenets region. This is situated in the Ural Federal District, which is in RU2 in the model. Several of the main pipelines connect this area with the 
western part of Russia and Europe. Through using several maps of the Russian gas pipeline network (EEGA and Petroleum Economist, see http://www.petroleum-economist.com/Map-

Store.html? Is=training), and an overview of existing infrastructure (Nies 2011), a set of capacities between the three Russian regions, as well as export capacities to Europe, Ukraine (UA), Belarus (BY) and rest of the world (ROW) have been created, see Table 4. It is assumed that all capacities are symmetrical.

Table 4. International transmission capacities for natural gas in 2009. Mtoe

\begin{tabular}{|c|c|c|c|c|c|c|c|}
\hline From & EU30 & BY & UA & ROW & RU1 & RU2 & RU3 \\
\hline EU30 & - & 15 & 162 & 10 & 61 & 0 & 0 \\
\hline BY & 15 & - & 0 & 0 & 33 & 0 & 0 \\
\hline UA & 162 & 0 & - & 0 & 138 & 0 & 0 \\
\hline ROW & 10 & 0 & 0 & - & 71 & 0 & 8 \\
\hline RU1 & 61 & 33 & 138 & 71 & - & 382 & 0 \\
\hline RU2 & 0 & 0 & 0 & 0 & 382 & - & 19 \\
\hline RU3 & 0 & 0 & 0 & 8 & 0 & 19 & - \\
\hline
\end{tabular}

As stated above, the market share of Russian gas in the European market is substantial and Gazprom has monopoly in export of natural gas from Russia. These observations suggest that Russia may exert market power. The extent to which Russian actually exerts market power is an empirical question, and we have therefore calibrated a parameter that reflects the degree of market power. The calibration builds on standard economic theory: whereas a price taker equates its marginal cost to the output price, marginal cost of an actor exerting market power is lower than the output price. In the latter case the actor cuts back on his level of activity (relative to the competitive case), thereby taking into account that the price depends negatively on total production. We model this mechanism by imposing a mark-up on export of natural gas from Russia towards Europe.

The mark-up on Russian gas is determined as follows: We introduce a mark-up on export of natural gas from Russia and run LIBEMOD for the data year 2009. We impose that export of Russian gas to Europe is equal to the observed quantity in 2009. This requires that the mark up is $17 € /$ toe. This mark-up is applied in Section 5 when we run LIBEMOD under alternative scenarios.

\section{Prices and Taxes}

IEA (2011c) provides prices for some sectors for Russia in 2009. However, because the prices of gas and electricity vary considerably between regions and user groups, various Russian sources have been consulted to create a more representative set of prices for each LIBEMOD region. Two scenario reports published by the Agency for Forecasting (under the Ministry of Energy of the Russian Federation) have forecast prices for each of the seven federal regions for 2009 and 2010 (see APBE, $2008,2010 b$ ). These prices are used to calibrate the difference between energy prices in RU1, RU2 and RU3 taking the national Russian prices from IEA (2011c). 
Finding user prices for the different sectors for natural gas has not been straightforward. Two sets of gas tariffs for the 83 regions from the Federal Tariff Service (FTS) in Russia have been used as a starting point (http://www.fstrf.ru/tariffs/info_tarif/gas). These are the prices Gazprom charges the distribution companies, depending on whether they sell the gas to households or wholesale customers.

The end-user price to households is regulated and is published each year by the regional tariff authority. To find the end-user prices for households in 2009, regional websites were consulted and a dataset from the available prices was created. This, along with the tariffs from the FTS, was used to determine how the end-user price of gas varies from region to region, see Table 5. IEA Energy Prices and Taxes has a national natural gas price for industry in Russia in the base year. Joint with regional forecast prices from APBE (2008), we found the natural gas prices for industry for the three LIBEMOD regions.

Table 5 also provides information about implicit subsidies to users of natural gas in different sectors and different parts of Russia. To derive these subsidies we first constructed hypothetical user prices as follows: We used the observed producer prices of natural gas in different Russian regions and added our estimates for costs of transport and distribution of gas (corrected by losses in transport and distribution) and all types of taxes. We then defined the region- and sector-specific subsidies as the differences between these constructed hypothetical user prices of gas and the corresponding actual user prices of natural gas in 2009. As seen from Table 5, the (implicit) natural gas subsidies vary between 120 and $166 € /$ toe. Subsidies are slightly higher in RU1 than in RU2, and also slightly higher in RU2 than in RU3. Also, subsidies are higher for households and services (small customers) than for industry and electricity producers (large customers).

Table 5. User prices (subsidies) of natural gas by sector and Russian region in 2009. $€_{2009} /$ toe

\begin{tabular}{lccccc}
\hline Region & Households & Industry & Transport & $\begin{array}{c}\text { Electricity } \\
\text { producers }\end{array}$ & Services \\
\hline RU1 & $60(157)$ & $84(129)$ & - & $84(129)$ & $84(166)$ \\
RU2 & $52(148)$ & $65(125)$ & - & $65(125)$ & $65(161)$ \\
RU3 & $64(149)$ & $60(120)$ & - & $60(120)$ & $60(157)$
\end{tabular}

\section{Numerical results}

\subsection{Alternative scenarios for 2020}

Table 6 shows the scenarios we consider. All scenarios apply to the year 2020, which means that economic and population levels have changed compared to the base year 2009. Further, parts of the installed production and transport capacities in 2009 have been depreciated. On the other hand, investments in new capacities are allowed, and are undertaken if profitable in the given scenario. Investments in pipelines from Russia to Europe are not endogenous in most scenarios, however. Instead we consider separate scenarios where such investments are allowed. 
The supply of gas from Russia and EU-30 countries, as well as imports of LNG and piped gas from non-European countries, is different in 2020 than in 2009 (for given gas prices). As Gazprom has longterm contracts (with some flexibility) for large volumes of gas beyond 2020, we require that total net export of gas from Russia does not fall below the 2009 level, which was the lowest export level since the Soviet era. This restriction is only binding in the Reference scenario. Finally, policies have changed from 2009 to 2020, as we e.g. assume the EU climate and renewable targets to be achieved in 2020.

Table 6. Alternative scenarios for 2020

\begin{tabular}{|l|l|}
\hline Reference & $\begin{array}{l}\text { No changes in subsidies or market structure in Russian energy } \\
\text { market }\end{array}$ \\
\hline No industry subsidies & Gas subsidies to industry and electricity generation are removed \\
\hline Competitive & All gas subsidies and all energy market imperfections are removed \\
\hline No export tax & Same as “Competitive”, but no export tax on Russian gas export \\
\hline High pipeline depreciation & $\begin{array}{l}\text { Same as “Competitive”, but 5\% annual depreciation of pipelines } \\
\text { from and within Russia, Ukraine and Belarus (instead of 2.5\%) }\end{array}$ \\
\hline South Stream & $\begin{array}{l}\text { Same as “High pipeline depreciation", but South Stream pipeline } \\
\text { capacity available }\end{array}$ \\
\hline Competitive gas export & $\begin{array}{l}\text { Same as “High pipeline depreciation", but no export tax or markup } \\
\text { on Russian gas export, and endogenous pipeline investmentsd }\end{array}$ \\
\hline
\end{tabular}

In our Reference scenario, the market structure and energy demand subsidies are the same as in the base year. Note that this is not necessarily the most realistic scenario. In the scenario "No industry subsidies" we simulate the effects of removing subsidies on gas use in the industry and power sectors. In the "Competitive" scenario all gas subsidies are removed. In other words, user prices of natural gas are no longer regulated in this scenario - instead they are fully determined in the market. Moreover, all energy market imperfections are also removed (other energy subsidies are not changed though). This means that there are no longer any mark-ups in the transport and distribution of gas and electricity. We have also simulated more intermediate scenarios, which we briefly comment on below. In particular, the "Competitive" scenario is almost identical to a scenario where all gas subsidies are removed, but energy market imperfections are not.

In the next four scenarios we consider different export conditions. Common to those scenarios is that we assume no gas subsidies and no energy market imperfections (i.e., taking the "Competitive" scenario as a starting point). In "No export tax" we examine the effects of removing the Russian tax on gas export. This gross tax increases the marginal export delivery costs for Gazprom, and hence reduces the profitability of exporting. In "High pipeline depreciation" we instead consider a scenario where the gas pipeline capacity between Russia and the EU market has declined more rapidly than assumed in the other scenarios, reducing the export potential: The existing pipeline network from Russia to the EU (and within Russia) is quite old with substantial gas leakages. Consequently, it may have to be replaced more rapidly than the pipelines within the EU. The "South Stream" scenario takes the previous scenario as a starting point, but assumes that a pipeline between Russia and 
Southeastern Europe has been built (see more details below). Finally, in "Competitive gas export" we also assume high depreciation of existing gas pipelines, but allow for endogenous (profitable) investments in new pipeline capacity between Russia and the EU market. These are held fixed in the other scenarios (as opposed to international gas pipelines within EU-30 which are endogenous in all scenarios). In the "Competitive gas export" scenario, we also assume no export tax and no markup on Russian gas export. Again, we have also simulated intermediate scenarios, which we briefly touch upon in the text.

\subsection{Reference scenario}

We start by considering the Reference scenario and compare it to the historical base year 2009. Figure 2 shows the user prices of natural gas in Russia and EU-30. These are weighted average prices over all sectors (including the electricity sector) and Russian regions/EU countries. The figure clearly shows the huge difference between gas prices in Russia and EU-30, both in 2009 and in the reference scenario for 2020. User prices in EU-30 were on average more than ten times higher than in Russia in 2009. The main reason is the low regulated gas prices in Russia. In addition comes the fact that Russian gas consumers are located much closer to the main supplier of natural gas than the European consumers. Hence, the total delivery costs are lower for Russian customers. Moreover, whereas natural gas is subsidized in Russia, EU consumers are on average taxed (by 31 Euro per toe in the base year 2009).

Figure 2. Weighted user prices of natural gas. $€_{2009} /$ toe

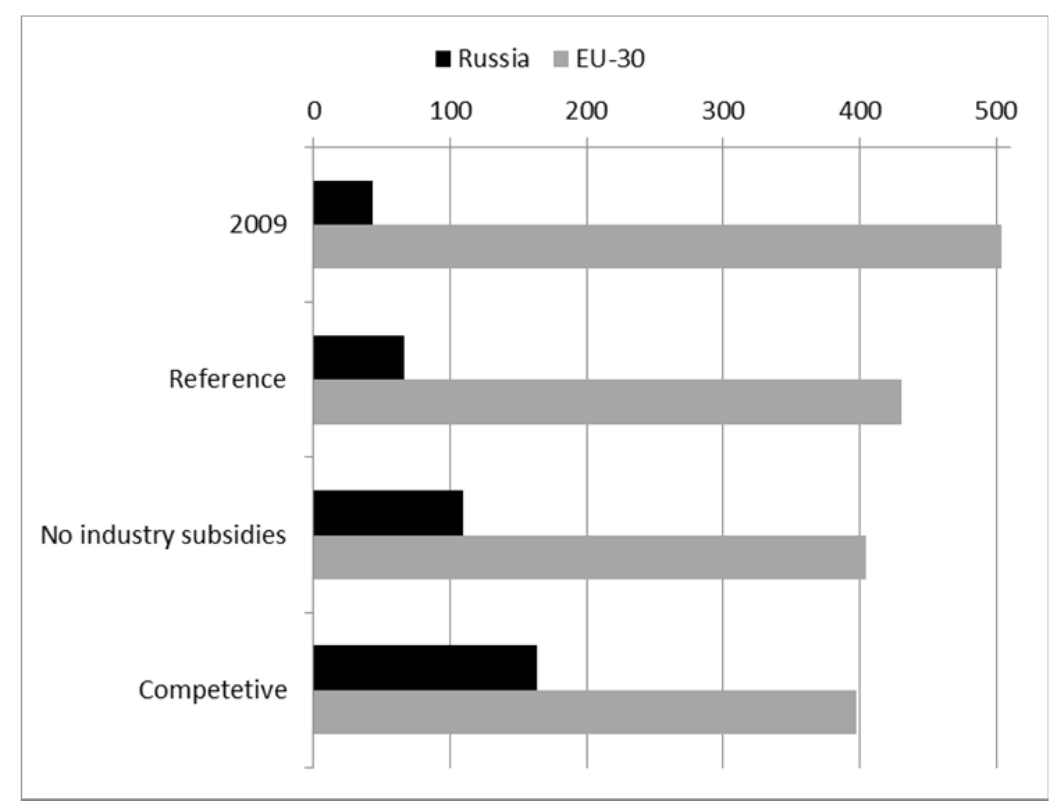

We also notice from Figure 2 that Russian user prices of gas increase slightly towards 2020 (the reference scenario), whereas European user prices decline. This reflects a stronger development in gas demand in Russia than in EU-30 between 2009 and 2020 in our reference scenario, combined with somewhat higher Russian production costs and the Russian export restriction in the reference scenario. Figure 3 confirms this - it shows that gas consumption in EU-30 slightly declines in this period despite lower prices, mainly due to less generation of gas power, which again is due to a 
combination of EU climate and renewable policies. Russian gas consumption, on the other hand, increases slightly despite a price increase of $50 \%$ from 2009 to $2020 .^{6}$

Figure 3. Gas consumption. Mtoe/year

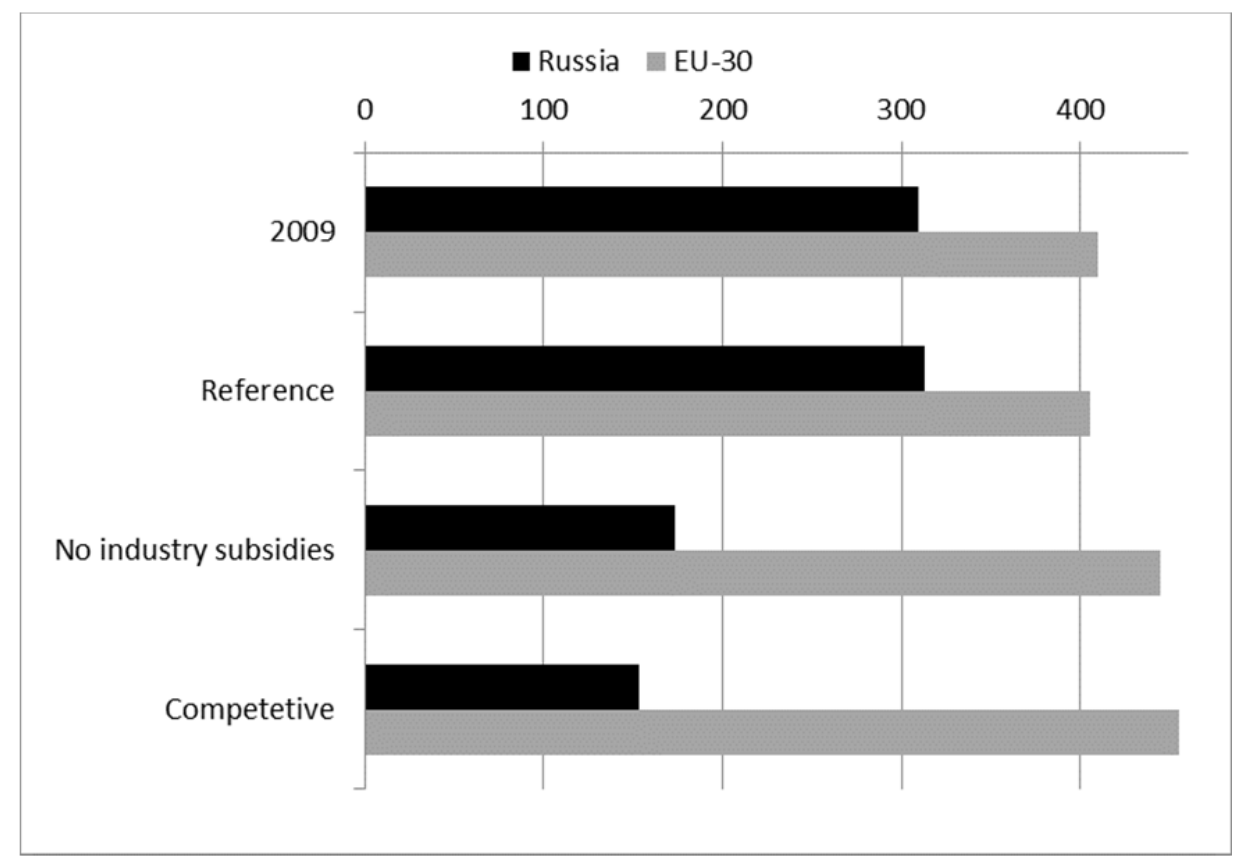

With reduced demand for gas in EU-30, the need for imported gas declines. Moreover, increased gas demand in Russia makes less gas supply available for exports. Thus, without the export restriction in the reference scenario, total net gas export would have dropped to 72 mtoe. Instead, the export level is kept at 129 mtoe in the reference scenario, see Figure 4.

\footnotetext{
${ }^{6}$ Note that our gas consumption levels do not include neither use of gas nor losses in gas extraction, transportation and distribution. Hence, our aggregate numbers for gas use will tend to be lower than corresponding aggregate numbers in e.g. IEA's World Energy Outlook (IEA, 2010) and BP's Statistical Review of World Energy (BP, 2010). This is especially the case for Russia, where gross gas use is notably higher than net gas use.
} 
Figure 4. Net export of gas from Russia. Mtoe/year

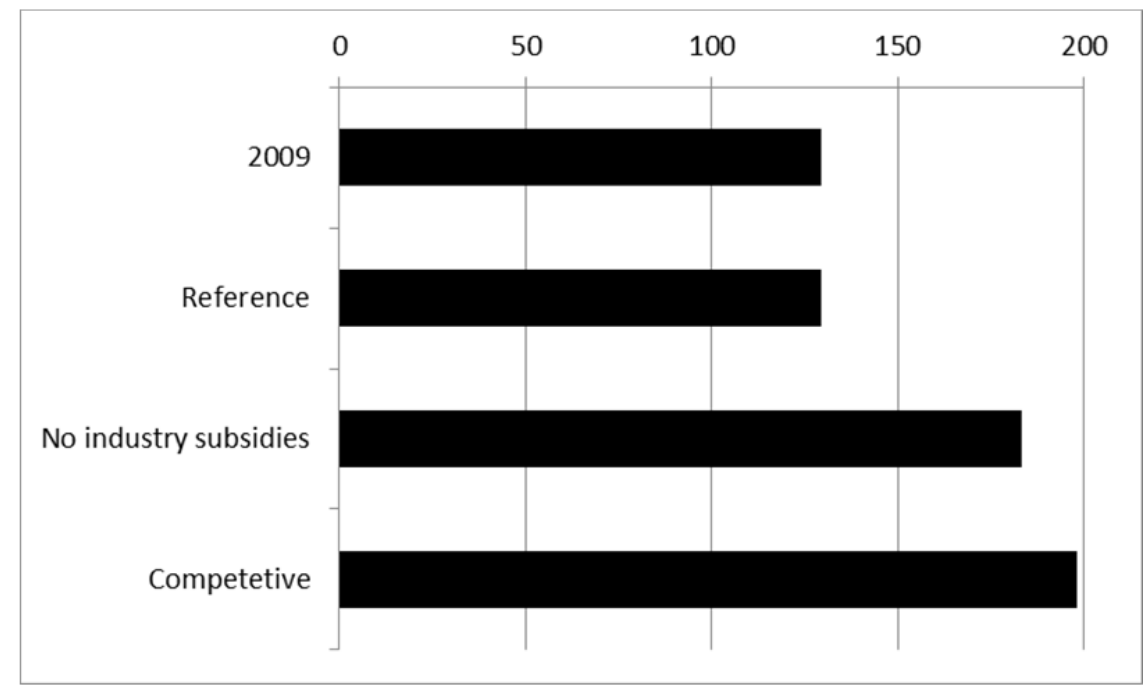

\subsection{Removing subsidies and market imperfections}

We now turn to the alternative scenarios for 2020, and first we consider the effects of removing the subsidies to gas use. In the case where industries and gas power plants have to pay market prices for gas ("No industry subsidies"), we see from Figure 5 that industries pay much higher gas prices than in the reference scenario. We find similar price changes for power plants. An interesting observation in the figure is that end-user prices for households decline substantially in this case. The main reason is a huge drop in gas power production, see Figure 6, which reduces the demand for gas, implying much lower prices in the Russian gas market. Total use of gas in Russia is almost halved in this scenario visà-vis the reference scenario, see Figure 3 .

When all Russian gas consumers have to pay market prices ( cf. the "Competitive" scenario), households' gas prices rise by a factor of five, while their gas consumption is almost halved, compared to the "No industry subsidies". When comparing to the reference scenario, the changes are less dramatic but still substantial. We also notice that gas prices for industries decline slightly when all subsidies are eliminated, which again is due to reduced market price of gas in Russia caused by lower demand.

Eliminating gas subsidies completely may seem unrealistic, especially within less than ten years. A more realistic scenario could be that subsidies to industries and power production are halved, whereas subsidies to households are not changed (not included in the figures). This would in fact also have a substantial effect on total Russian gas consumption, which is then reduced by more than $20 \%$. 
Figure 5. Gas price Russia for households and industry. $€_{2009} /$ toe

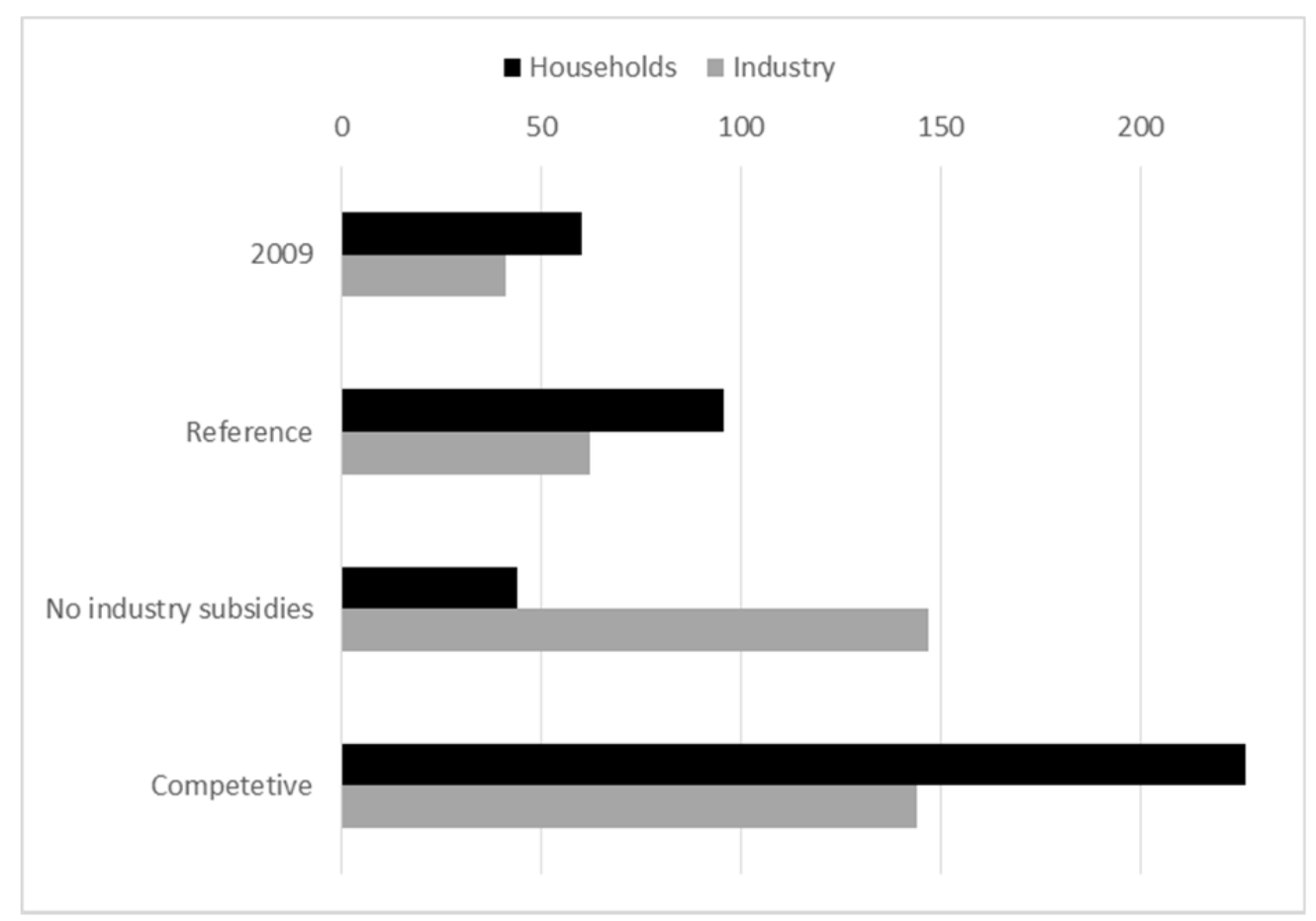

Removing subsidies has large impacts on gas exports from Russia to EU-30, see Figure 4 which also includes 7 Mtoe exports to the Asian market (equal across all scenarios). If gas subsidies to industries and power plants are removed ("No industry subsidy"), the net export level becomes 183 Mtoe, i.e., about $40 \%$ above the 2009 (and reference) level. This is also slightly more than the export levels observed after 2009. If all subsidies are eliminated, and all market imperfections in the domestic Russian energy markets are removed ("Competitive"), net gas exports increase by an additional 15 Mtoe, and then there is almost no spare capacity in the gas pipelines between Russia and the EU market. $^{7}$

Increased gas exports from Russia to EU-30 have a noticeable effect on European gas consumption, which increases by more than $10 \%$ in the "Competitive" scenario compared to the reference scenario, see Figure 3. This is mostly due to more gas power production in Europe, as average user prices of gas have been reduced by almost $10 \%$ (see Figure 2). Gas prices paid by gas power plants are reduced even more in relative terms.

\footnotetext{
${ }^{7}$ If for some reason Russia were not able to increase its gas exports when removing subsidies to industries and electricity generation, market prices within Russia would have fallen even more. Then gas consumption in Russia would not have dropped as much, especially because of less reductions in gas power production.
} 
Figure 6. Gas consumption in Russia by end user. Mtoe/year

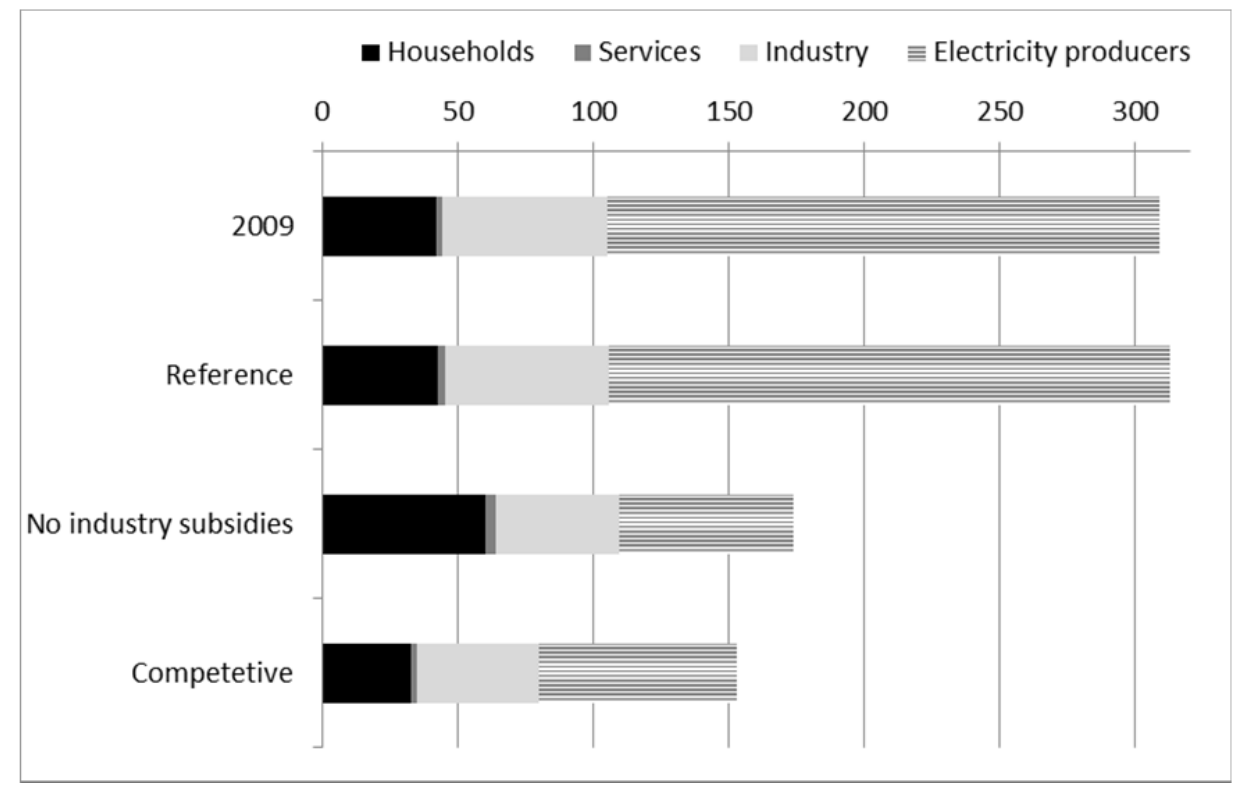

It is also interesting to look more closely at the changes in the Russian energy markets. Figure 7 shows end-use consumption of different types of energy in Russia. We see large changes in gas consumption across scenarios, especially when all gas subsidies are eliminated in the "Competitive" scenario. When only subsidies to industries and power plants are removed, total end-use consumption of gas actually increases somewhat (gas used to produce electricity is not included here). On the other hand, we see that electricity consumption drops notably in the "Competitive" scenario, caused by higher costs of electricity generation. Gas power accounts for around $60 \%$ of total electricity generation in the reference scenario, and hence higher user prices of gas for gas power plants in the "Competitive" scenario lead to higher marginal production costs in the electricity sector. End use of coal increases slightly when gas subsidies are removed, but the biggest effects for coal are seen in electricity generation where it increases its market share from $20 \%$ in the reference scenario to above $40 \%$ in the "Competitive" scenario. 
Figure 7. End-user consumption by energy carrier in Russia. Mtoe/year

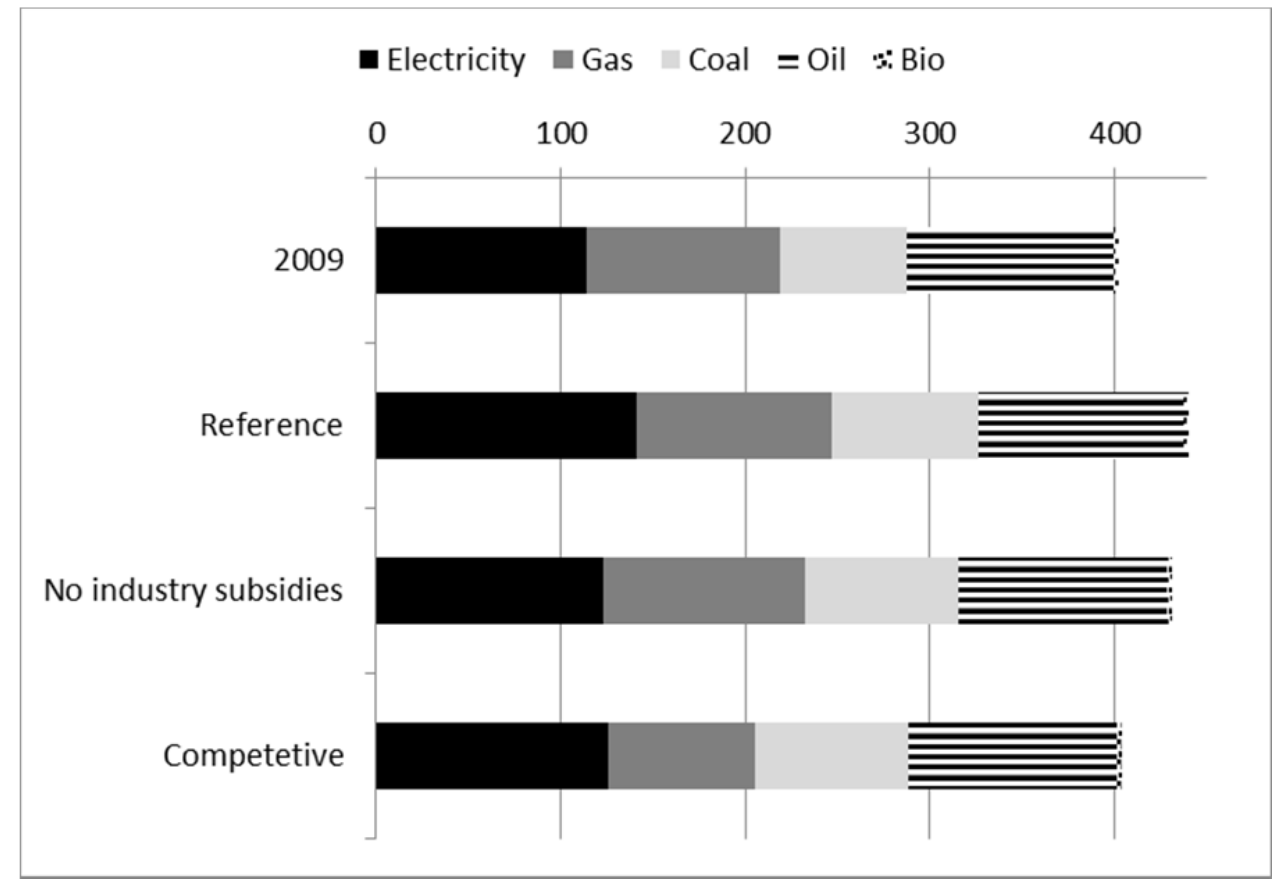

Figure 8 shows how (weighted) average user prices of gas change in the three regions of Russia (the prices shown for Russia are the same as in Figure 2). We see that the gas price in Middle Russia is lowest in 2009 and in the reference scenario, partly because most of the gas production takes place in this region - it is costly to transport gas between the regions due to the large distances. When subsidies to industries and electricity generation are removed, we see from the figure that the weighted gas price in Middle Russia increases more than in other regions. The reason is that more than $90 \%$ of gas consumption in this region is used in the industry and electricity sectors in the reference scenario. Hence, although prices to individual sectors are still lowest in Middle Russia, the weighted average price is almost identical to the one in Eastern Russia. The same is true in the "Competitive" scenario.

Removing gas subsidies and other imperfections in the Russian gas market will increase efficiency. Thus, we should expect economic welfare to improve compared to the Reference scenario, even though gas consumers will lose from higher prices. This is confirmed by the numbers in Table 7. When subsidies to industries and electricity generation are removed, total welfare in Russia increases by more than 3 billion Euro per year according to our results. The table further shows that there are major winners and losers from this change in regulation. Russian energy consumers in total (i.e., all end users of energy) lose 20 billion Euro, whereas Russian gas producers gain 14 billion Euro. This is mainly due to the removal of the implicit subsidy, which means that gas producers can sell gas to market prices (to industries and power producers). Moreover, Russian gas producers increase their export of gas to Europe as domestic consumers demand less gas than in the Reference case, cf. Figure 4 above. 
Figure 8. Weighted user prices of natural gas. $€_{2009} /$ toe

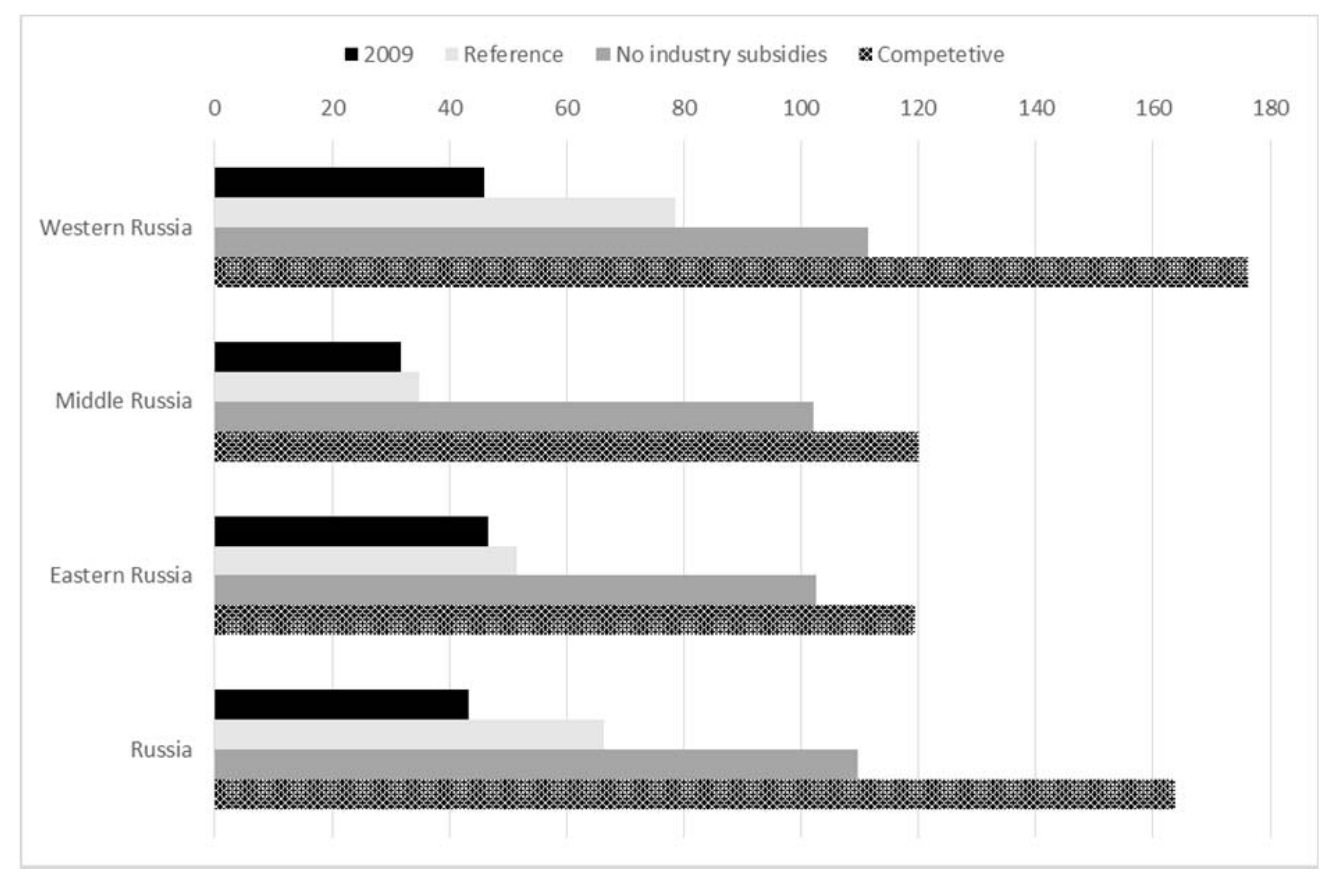

The big loss in consumer surplus is partly due to higher gas prices for the industry sector, but also due to substantially higher electricity prices for all sectors. This is caused by the removal of the implicit subsidy of gas prices in the electricity sector, and the fact that gas power accounts for more than half of all electricity generation in Russia (both in the base year and in the Reference scenario). Hence, even though gas power production drops significantly in the "No industry subsidies" scenario, the price of electricity increases quite a lot. As seen in Table 7, power producers as a group actually benefit significantly from the removal of the implicit subsidy on their gas inputs.

Table 7. Russian welfare by group relative to the Reference scenario. Billion $€_{2009}$ per year

\begin{tabular}{lcc}
\hline & No industry subsidies & Competitive \\
\hline Consumer surplus & -20.2 & -25.1 \\
Producer surplus gas & 14.2 & 23.8 \\
Trader surplus & 2.2 & 3.1 \\
Producer surplus power & 6.5 & 5.1 \\
Government & 0.5 & 1.3 \\
\hline Sum & $\mathbf{3 . 2}$ & $\mathbf{8 . 0}$ \\
\hline
\end{tabular}

As already mentioned, gas producers' profit increase by 14 billion in this scenario. In addition, there is an increased trader surplus of 2.2 billion, which benefits the owners of pipelines and (electricity) transmission lines between Russia and neighboring countries and between the three Russian regions. Trader surplus arises when pipeline (transmission) capacities are exhausted, and there is a price 
differential that exceeds the operating costs of transporting the gas (electricity). ${ }^{8}$ In this scenario, the increased trader surplus is almost exclusively due to higher transport margins on exports of Russian gas.

When implicit gas subsidies are removed also in the household and service sectors, and other market imperfections are removed too, total welfare increases to 8 billion Euro per year, see Table 7. We notice that consumer surplus is further reduced to 25 billion, while gas producers' profit rises to 24 billion. This reflects that the average domestic gas price in Russia increases significantly in this scenario, while domestic consumption does not decline that much compared to the "No industry subsidies" scenario (cf. the figures and discussion above). Trader surplus also increases slightly more, while profits for power producers increase slightly less.

\subsection{Alternative export and pipeline scenarios}

We now turn to scenarios where we consider different export conditions for Russian gas export to Europe. These conditions relates to gas export taxes, markup in Russian gas export, and pipeline capacities between Russia and EU-30. The starting point of all these scenarios is the "Competitive" scenario, i.e., a competitive energy market with no subsidies on gas use.

When exporting gas, Gazprom has to pay a tax of $30 \%$ of its revenue. Being a gross tax on income rather than a tax on profits, it is likely to reduce the profitable level of export for the company. Thus, when we simulate the scenario "No export tax", we should expect higher export of gas from Russia. This is also the case - net export increases but only marginally (see Figure 9). The reason for the small effect is that gas export is already high in the "Competitive" scenario, with little spare transmission capacity. Without increased pipeline capacity between Russia and the EU market, it is not possible to expand export much. Thus, the effects on gas prices and gas consumption in Russia and EU-30 are not much affected neither, see Figures 10 and 11.

Figure 9. Net export of gas from Russia. Mtoe/year

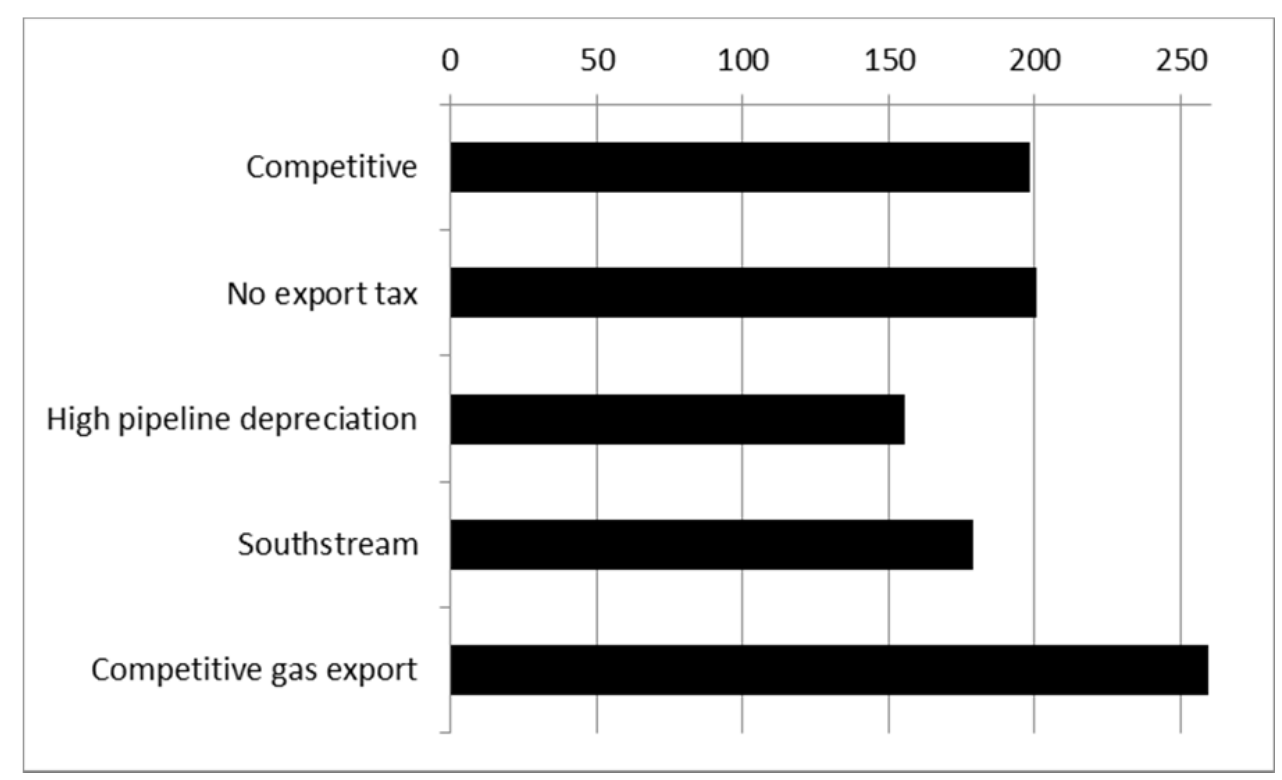

\footnotetext{
${ }^{8}$ The general assumption in LIBEMOD is that trader surplus is split into two, so that the exporter and importer share the trader surplus equally.
} 
The net welfare effect for Russia of eliminating the export tax is negative, see Table 8 which shows welfare by group relative to the "Competitive scenario". The lost revenue for the government (no export tax) is partly offset by increased trader surplus, but since trader surplus is split equally between exporters and importers, some of the higher trader surplus accrue to non-Russian traders.

A quite different outcome will emerge if the pipeline capacity between Russia and EU-30 for some reason declines more rapidly than in the Reference scenario. So far, we have assumed an annual depreciation of all transmission capacities of $2.5 \%$ per year. In the "High pipeline depreciation" scenario we consider a doubling of the annual depreciation rate for all gas transmission capacities between Russia and EU-30 (and between the three regions within Russia). This implies more than $40 \%$ reduction in the pre-existing 2009 pipeline capacity (until 2020), compared to $25 \%$ reduction in the Reference and Competitive scenarios. Naturally, gas exports from Russia fall markedly in this scenario compared to the "Competitive" scenario, see Figure 9. However, despite the substantial decline in pipeline capacity, Russian net export is still significant and higher than in the base year 2009 (but slightly below the levels in the years 2010-2013). This further illustrates that current pipeline capacity between Russia and EU-30 is extensive with much spare capacity.

Figure 10. Weighted user prices of natural gas. $€ 2009 /$ toe

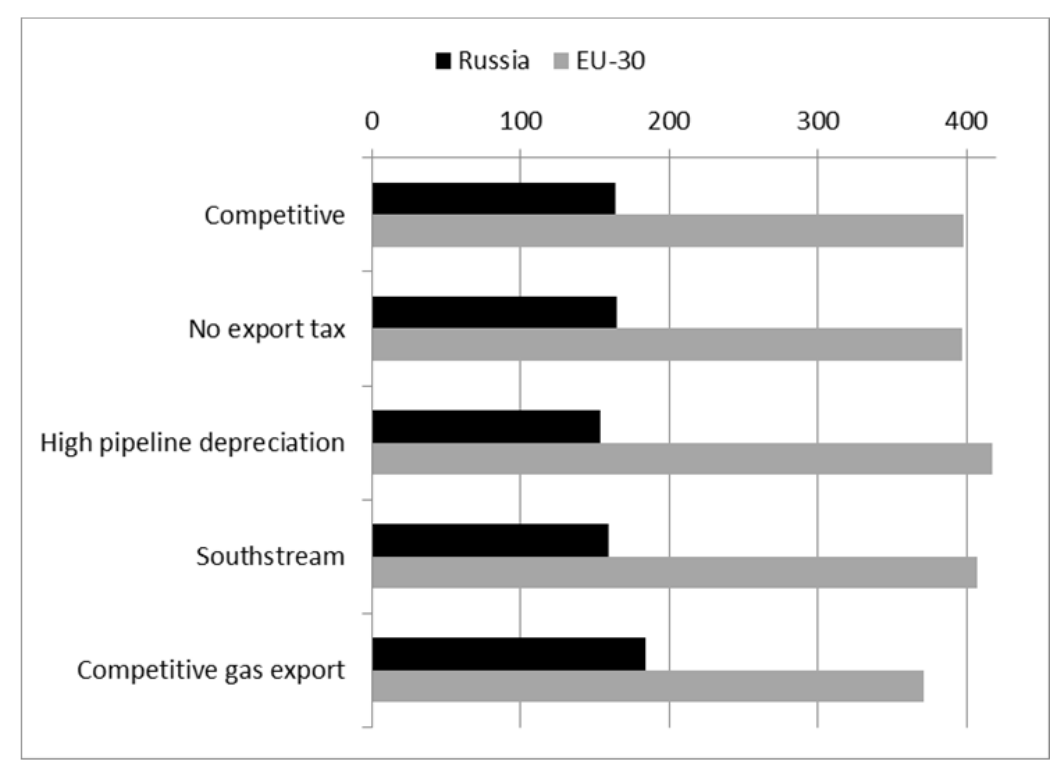


Figure 11. Gas consumption. Mtoe/year

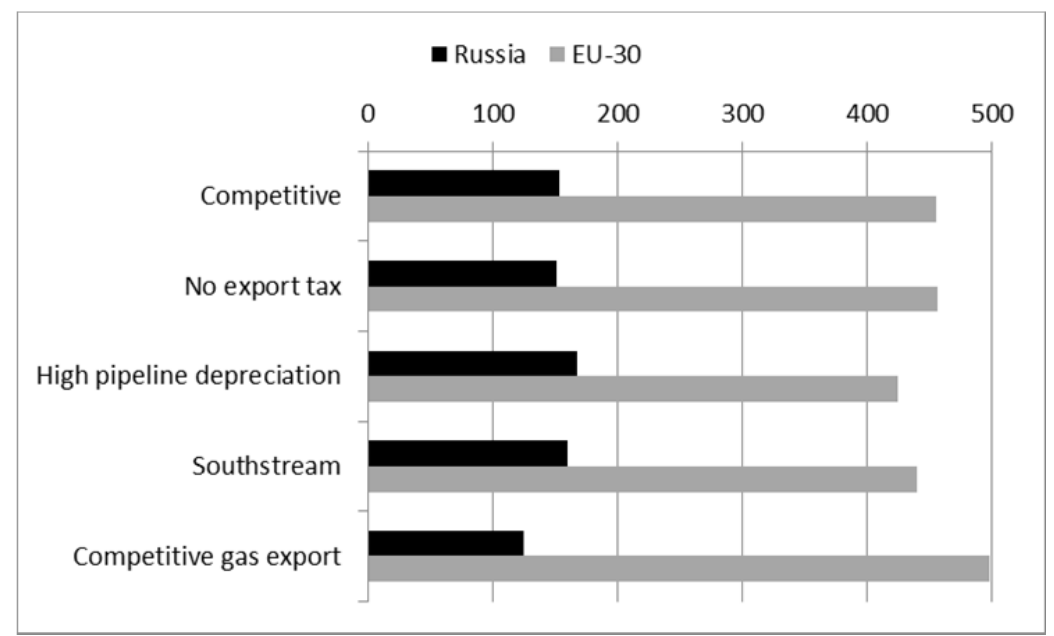

Table 8. Welfare in Russia by group relative to the Competitive scenario. Billion $€_{2009}$ per year

\begin{tabular}{lcccc}
\hline & No export tax & $\begin{array}{c}\text { High pipeline } \\
\text { depreciation }\end{array}$ & South Stream & $\begin{array}{c}\text { Competitive } \\
\text { gas export }\end{array}$ \\
\hline Consumer surplus & -0.2 & 1.8 & 0.8 & -3.2 \\
Producer surplus gas & 0.2 & -3.9 & -1.8 & 2.4 \\
Trader surplus & 3.9 & -0.5 & -1.4 & 0.2 \\
Producer surplus power & 0.1 & -0.3 & -0.2 & 0.9 \\
Government & -7.6 & -1.2 & -0.7 & -8.3 \\
\hline Sum & $-\mathbf{3 . 7}$ & $-\mathbf{4 . 1}$ & $\mathbf{- 3 . 3}$ & $\mathbf{- 7 . 9}$ \\
\hline
\end{tabular}

In the "High pipeline depreciation" scenario, export of natural gas from Russia is $21 \%$ lower than in the "Competitive" scenario. The lower export of gas from Russia to EU-30 implies that more gas is available in the Russian domestic market. Thus, Russian gas consumption expands by $10 \%$ while average user prices of natural gas in Russia drops by 6\%, see Figures 10 and 11 (the user prices are weighted over all sectors, including the electricity sector). Higher gas consumption comes almost exclusively in the electricity sector, where existing and new gas power plants increase production partly at the expense of coal power production. In EU-30, we get the opposite effect - gas prices increase by $5 \%$ while gas consumption decreases by $7 \%$. Gas power production in EU-30 drops by more than $20 \%$, whereas both coal power and electricity from renewables (especially bio power) expand considerably.

Russian welfare naturally declines if pipelines depreciate more rapidly, cf. Table 8. The main losers are obviously gas producers, but also the government due to less export tax revenues. Energy consumers benefit though due to lower domestic gas prices. Trader surplus between Russia and other countries increases as more of the capacity if fully utilized, whereas trader surplus between Russian regions decline due to less transport from Middle Russia to Western Russia.

In 2007 the South Stream pipeline was announced, going from Russia to Bulgaria through the Black Sea. Given the substantial existing pipeline capacity between Russia and the EU market, the 
profitability of this pipeline could be questioned. However, building such a pipeline may be seen as a strategic move by Russia, reducing the profitability of competing projects such as the proposed Nabucco pipeline with gas from Middle Eastern and Caspian countries. Some construction has been initiated on the Russian side of the Black Sea. However, in late 2014 the South Stream pipeline was abandoned because of disagreements between Russia and the EU about third party access. Instead, Russia launched a plan for extension of the pipeline to Turkey - called Turkish Stream or Turk Stream - and further to the Balkans, which would ultimately deliver $47 \mathrm{BCM}$ on the border to Greece. ${ }^{9}$ In our "South Stream" scenario we have implemented the original South Stream project, but the impacts would only change marginally if the Turk Stream pipeline was implemented instead.

If we simply add the South Stream capacity to the "Competitive" scenario, there is almost no changes in the net gas export from Russia. However, some of the gas is transported through the South Stream pipeline instead of through Ukraine - about $25 \%$ of the South Stream capacity is utilized. Thus, even if a more competitive Russian gas market should make more gas available for export, the need for the South Stream pipeline seems to be limited.

This conclusion changes, however, if the current pipeline capacity depreciates more rapidly, either literally or due to political considerations (Russia may limit its exports of gas through Ukraine). If we add the South Stream pipeline to the "High pipeline depreciation" discussed above, then gas export increases by $15 \%$ and most of the new pipeline capacity is utilized (cf. the "South Stream" scenario in Figure 9). Hence, the new pipeline would partly offset the higher depreciation of existing pipeline capacity, and gas prices and consumption levels in Russia and EU-30 end up in between the "Competitive" and the "High pipeline depreciation" scenarios, see Figures 10 and 11 . This is also the case for welfare effects, see Table 8, except for trader surplus which declines due to less instances of full capacity utilization.

Although the South Stream capacity would be used if it became available, it is not profitable to build the pipeline according to our simulations, even in a situation with rapid depreciation of existing pipeline capacity. ${ }^{10}$ When we allow for profitable pipeline investments between Russian and the EU market in the "High pipeline depreciation" scenario, no such investments take place. Partly, this reflects the high construction costs of new pipelines.

The lack of profitability of pipeline investments is also due to the export tax discussed above, and the markup assumed on Russian gas export. The markup is motivated by Russia's large market share in the European gas market - increased Russian gas sales would depress gas prices and hence reduce the profitability of Russian gas export. In our last scenario called "Competitive gas export", we consider a situation where both the export tax and the markup have been removed, mimicking a competitive Russian gas export behavior (cf. Tsygankova, 2010, 2012). We take the "High pipeline depreciation" scenario as a starting point, and again allow for investments in gas pipeline capacity between Russia and the EU. Net gas export from Russia then expands substantially; by two thirds compared to the "High pipeline depreciation" scenario (see Figure 9). Eliminating the export tax has the biggest impact on the export increase, but removing the markup has a sizable impact too.

\footnotetext{
${ }^{9}$ http://www.ft.com/intl/cms/s/0/b377fc9a-f4d0-11e4-8a42-00144feab7de.html\#axzz3arsVw4C2

${ }^{10}$ This could of course change if we looked further ahead than 2020. Our simulations apply for the year 2020, implicitly assuming a long-run equilibrium in that year. Also, if future market conditions should become more favorable for the pipeline, the conclusion could possibly change. However, then other pipelines could be more relevant, cf. the following discussion.
} 
With a large increase in gas exports from Russia to EU-30, the energy markets in Russia and the EU are significantly affected. Average gas prices in Russia increase by $20 \%$, reducing total Russian gas consumption by $25 \%$ compared to the "High pipeline depreciation" scenario, see Figures 10 and 11 . Again, it is mostly gas power production that is reduced. End-use consumption of gas in Russia drops by merely $3 \%$, whereas gas used for electricity generation drops by more than one third. This is partly offset by higher coal power production, so that total electricity generation decreases by only $2 \%$.

Gas prices and gas consumption in the EU-30 are also substantially affected, but not as much as in Russia, see Figures 10 and 11 . Average prices of gas in EU-30 decline by $11 \%$ while gas consumption rises by $18 \%$ (compared to the "High pipeline depreciation" scenario). Gas power production in EU30 expands by two thirds, while coal power and renewable electricity production drops by almost $20 \%$ and $15 \%$, respectively. This clearly demonstrates the crucial role of Russia in the European energy market, and the importance of Russia's export behavior. On the other hand, total electricity generation in EU-30 is increases by $1.3 \%$, and total energy consumption by $1.0 \%$, when both the export tax and the markup are removed, so the overall impacts for European energy consumers are rather modest after all.

Last but not least, the welfare impacts for Russia of such a competitive export behavior are negative, see Table 8. Naturally, consumer surplus declines because of higher gas prices. The government loses because it no longer receives any export tax revenues. This loss is partly offset by increased trader surplus, but because trader surplus is split equally between exporters and importers, some of the higher trader surplus accrues to non-Russian traders. Whereas Russia increases its share of the European gas market, the reduced gas prices in the EU dominates an overall there is thus a reduction in the net income of Russia.

\section{Concluding remarks}

The Russian gas market has been highly regulated since the Soviet era, with low regulated gas prices for consumers. Russian authorities have signalled a desire to reduce the difference between export prices and domestic prices of gas. In this paper we have examined how a shift towards more competitive gas prices could alter the Russian energy market and its export of gas to Europe. For this purpose we have used a detailed model of the energy markets in Europe and Russia (LIBEMOD), and simulated the model for the year 2020.

According to our results, removing the gas subsidies will significantly reduce consumption of natural gas in Russia. In particular, gas power production will shrink. Although Russian production of natural gas will drop due to less demand, a large part of the reduced gas consumption will be exported. Current pipeline capacity from Russia to the EU is sufficiently large to allow for a significant export growth without new pipeline investments. Removing gas subsidies will have positive welfare effects for Russia as a whole, even though energy consumers will be negatively affected. The implications of higher gas imports from Russia are somewhat lower gas prices and more gas power production in the EU.

If pipeline capacity should decline more rapidly than in our reference case, the benefits from additional pipelines like for instance the Turk Stream pipeline would be higher. The same holds if Russia should become more aggressive in its export behavior, e.g. by removing the export tax on natural gas and removing Gazprom's exclusive export rights. Our results indicate that expanding the 
pipeline capacity could then be profitable from a narrow business perspective. However, from a Russian welfare perspective such an expansion would be negative due to lower export prices.

The future development of the Russian gas market and gas exports to Europe depends on several economic and political factors in addition to the ones we have considered. First, costs of extraction of gas may increase over time. The World Bank has estimated that by 2001 the long-run marginal cost of Russian gas was between 35 and 40 USD per 1000 m3, see Tarr (2010). This is much lower than the 2013 'consensus estimate' of break-even costs for new fields in the Yamal peninsula, which was USD 120-140 per 1000 m3, see Henderson and Pirani (2014). Higher extraction costs will tend to reduce extraction and probably lower export of gas from Russia.

Second, there is a substantial potential for energy efficiency improvements in the Russian gas market. A joint study by the World Bank and Moscow's Center for energy efficiency concluded in 2010 that Russia had a theoretical saving potential of as much as $240 \mathrm{bcm}$ per year, see IFC/World Bank (2010). If a large part of this efficiency potential is realized, it could have a significant impact on Russian exports. Some of this efficiency improvement will likely be attained if domestic gas prices are raised.

Third, in 2014 Russia and China signed an agreement involving substantial exports of gas (by pipeline). In a companion paper we will investigate the impacts of the emerging Asian markets and how these may affect Russian gas exports to Europe. We will also consider potential implications of the tension between Russia and the EU due to the conflict in Ukraine. A large part of Russian gas exports to the EU goes through Ukraine, and Russia may be interested in routing more of the gas outside Ukraine. On the other hand, the EU may then reduce its reliance on Russian gas. 


\section{References}

Abdurafikov, R. (2009). Russian electricity market - Current state and perspectives, VVT Working Papers 121. Vuorimiehentie: VVT.

АРВЕ (2008). СЦЕНАРНЫЕ УСЛОВИЯ РАЗВИТИЯ ЭЛЕКТРОЭНЕРГЕТИКИ РОССИЙСКОЙ ФЕДЕРАЦИИ НА 2009-2020 ГОДЫ (Scenario conditions for electricity in the Russion Federation from 20092020). Moscow: Агентство по прогнозированию балансов в электроэнергетике.

APBE (2010a). Functioning and Development of the Electric Power Industry of the Russian Federation in 2009. Moscow: Energy Forecasting Agency.

АРВЕ (2010b). СЦЕНАРНЫЕ УСЛОВИЯ РАЗВИТИЯ ЭЛЕКТРОЭНЕРГЕТИКИ НА ПЕРИОД ДО 2030 ГОДА (Scenario conditions of electricity to 2030). Moscow: Министерство энергетики Российской Федерации Агентство по прогнозированию балансов в электроэнергетике (Ministry of Energy of the Russian Federation).

APBE (2011). Analysis of prices, tariffs and competition development in the retail electricity markets of the Russian Federation in 2009-2010. Moscow: Energy Forecasting Agency.

Aune, F., R. Golombek, S. A. C. Kittelsen and K. E. Rosendahl (1998). Liberalizing European Energy Markets - An Economic Analysis. Edward Elgar Publishing.

BP (2010). BP Statistical Review of World Energy 2010. London: BP.

East European Gas Analysis (2014). 9 May, 2014. http://www.eegas.com/rep2013q4-cost e.htm.

Gazprom (1998). Annual Report 1998.

Gazprom (2013). Setting fair gas prices in Russia to boost domestic economy. Press release from Gazprom, 22 April 2013.

Goldthau, A. (2008). Rhetoric versus reality: Russian threats to European energy supply. Energy Policy, 36 (2), 686-692.

Golombek, R., K. A. Brekke and S.A.C. Kittelsen (2013). Is electricity more important than natural gas? Partial liberalizations of the Western European energy markets. Economic Modelling, 35, 99111.

Golombek, R., S.A.C. Kittelsen and K.E. Rosendahl (2013). Price and welfare effects of emission quota allocation, Energy Economics 36, 568-580.

Grimsrud, K.G., K.E. Rosendahl, H.B. Storrøsten and M. Tsygankova (2015): Short run effects of bleaker prospects for oligopolistic producers of a non-renewable resource, forthcoming in The Energy Journal.

Hartley, P. and K. Medlock (2009). Potential futures for Russian natural gas exports. Energy Journal. 73-95 (Special Issue on World Natural Gas Markets and Trade).

Henderson, J. and S. Pirani (2014). The Russian Gas Matrix - How Markets are Driving Change. Oxford: Oxford University Press. 
Hirschhausen, C. von, B. Meinhart and F. Pavel (2005). Transporting Russian Gas to Western Europe - A Simulation Analysis, The Energy Journal 26 (2), 49-68.

IEA (2003). Renewables in Russia - From opportunity to reality. Paris: OECD/IEA.

IEA (2009). World Energy Outlook 2009. Paris: OECD/IEA.

IEA (2010). World Energy Outlook 2010. Paris: OECD/IEA.

IEA (2011a). Are we entering a golden age of gas? Special Report OECD, Paris.

IEA (2011b). Extended world energy balances. Retrieved from IEA World Energy Statistics and Balances (database): stats.oecd.org/.

IEA (2011c). Energy Prices and Taxes, Vol. 2010/1. Paris: OECD Publishing.

IEA (2012). Electricity Information. Paris: OECD/IEA.IEA (2014). Russia 2014 -Energy Policies Beyond IEA Countries. Paris: IEA.IFC/World Bank (2010): Energy Efficiency in Russia: Untapped Reserve. Moscow.

Interfax Russia \& CIS Oil and Gas Weekly (2014). No. 34, 28.08.2014-03.09.2014.

Kryukov, V. and A. Moe (2013). The Russian Natural Gas Sector, in Alexeev, M. and S. Weber (eds.): Oxford Handbook of the Russian Economy. Oxford: Oxford University Press.

Nies, S. (2011). Oil and Gas Delivery to Europe, An overview of existing and planned infrastructures, New edition, Goverrnance Europeenne et Geopolitique de l'Energie. Paris: Institute Francais des Relations Internationales (IFRI).

OECD (2002). OECD Economic Surveys - Russian Federation. Paris: OECD.

OECD (2004). OECD Economic Survey of the Russian Federation. Paris: OECD.

OECD (2006). Optimising Russian Gas. Paris: OECD/IEA.

Paltsev, S. (2014). Scenarios for Russia's natural gas exports to 2050. Energy Economics, 42, 262-270.

Pirani, S. (2011). Elusive Potential: Natural Gas Consumption in the CIS and the Quest for Efficiency. Oxford: Oxford Institute for Energy Studies.

Rakitova, O., Ovsyanko, A., Sikkema, R., \& Junginger (ed), M. (2009). Wood Pellets Production and Trade in Russia, Belarus and Ukraine, Market Research report Pellets@tlas (WP 6.1 Assessment of international pellet trade developments in non-EU countries). Intelligent Energy Europe.

Richter, P. M. and F. Holz (2014). All quiet on the Eastern front? Disruption scenarios of Russian natural gas supply to Europe. Discussion papers no. 1383. DIW Berlin.

Rosstat (2010). Statistical Yearbook of Russia 2009. Moscow: Rosstat.

Rungi, A. (2012). Russian accession to WTO and gas efficiency. POLINARES working paper n. 57. http://www.polinares.eu/docs/d4-1/polinares wp4 chapter7.pdf.

RusHydro (2010). Annual Report 2009. Moscow: RusHydro.

Russian government (2007a). On improving state regulation of gas prices. Government resolution No. 333, 28 May 2007 http://www.rg.ru/2007/06/02/a159632.html. 
Russian government (2007b). On perfectioning state regulation of gas prices. Government resolution no. 333, 28 May 2007. http://www.rg.ru/2007/06/02/a159632.html.

Sagen, E. and M. Tsygankova (2008). Russian natural gas exports-Will Russian gas price reforms improve the European security of supply? Energy Policy, 36, 867-880.

SO (2011). Отчет о функционировании ЕЭС России в 2010 году, "United Energy Systems (UES) of Russia 2010 operations report". System Operator (in Russian).

Tarr, D.G. (2010). Export Restraints on Russian Natural Gas and Raw Timber: What Are the Economic Impacts? Policy research working paper 5195. Washington D.C.: The World Bank.

Tsygankova, M. (2008). Netback pricing as a remedy for the Russian gas deficit. Discussion papers no. 554, Statistics Norway. http://www.ssb.no/a/publikasjoner/pdf/DP/dp554.pdf.

Tsygankova, M. (2010): When is a breakup of Gazprom good for Russia? Energy Economics, 32, 908917.

Tsygankova, M. (2012): An evaluation of alternative scenarios for the Gazprom monopoly of Russian gas exports. Energy Economics, 34, 153-161.

UES (2010). United Energy Systems of Russia, 2010 operations report. Отчет о функционировании ЕЭС России в 2010 году.

Vedomosti (2013). 8 November 2013. http://www.vedomosti.ru/finance/news/18495151/lyudizaplatyat-za-biznes. 


\section{Appendix: Russian data}

\section{A.1 Supply of energy}

Fuels

The total oil and gas production for Russia is allocated between the three LIBEMOD regions through an unofficial regional dataset from Rystad Energy. This detailed dataset has been aggregated and a set of parameters have been calibrated for gas and oil for the three regions.

The production of coking coal and steam coal has been made regional through the use of production data from Statistical Yearbook of Russia 2009 (Rosstat 2010). Despite having a large biomass potential, production of biomass is not well developed in Russia due to the costs being high compared to other energy alternatives. There is little production in the base year, and due to lack of data it is assumed that the biomass production is split equally between the three regions. The total for Russia is taken from IEA (2011b). Russia does not have any production of biofuels in the base year.

\section{Electricity}

We use IEA Electricity Information (IEA, 2012) as the main data source for electricity supply. To regionalise the data for electricity production APBE (2010) has been used. This publication provides production of electricity in power stations by fuel type, which allows the allocation of the use of coal, natural gas and oil to each region, see Table A1. For coal it is assumed that the same allocation applies for steam coal and lignite. This may cause the production shares of the different coal types to be flawed, but ensures that total production from coal in each region is correct. For generation from biomass no sources have been found, so the consumption has been allocated based on population shares.

Table A1 Electricity production in Russian regions in the base year (2009) in TWh

\begin{tabular}{lrrrr}
\hline & RU1 & RU2 & RU3 & Total \\
\hline Reservoir hydro & 51.1 & 6.7 & 113.5 & $\mathbf{1 7 1 . 3}$ \\
Pumped hydro & 4.8 & - & - & $\mathbf{4 . 8}$ \\
Run-of-river hydro & - & - & - & - \\
Natural gas power & 601.3 & 146.7 & 69.3 & $\mathbf{8 1 7 . 3}$ \\
Steam coal power & 19.0 & 37.2 & 134.7 & $\mathbf{1 9 0 . 9}$ \\
Lignite power & 11.1 & 21.4 & 75.4 & $\mathbf{1 0 7 . 9}$ \\
Oil power & 28.9 & 0.9 & 8.2 & $\mathbf{3 8 . 0}$ \\
Waste power & 4.1 & 2.0 & 2.3 & $\mathbf{8 . 4}$ \\
Bio power & 1.0 & 0.1 & 0.3 & $\mathbf{1 . 4}$ \\
Wind power & - & - & - & - \\
Solar power & - & - & - & - \\
Nuclear power & 151.8 & 3.6 & - & $\mathbf{1 5 5 . 4}$ \\
\hline
\end{tabular}

SO (2011) reports capacity data for thermal power, hydro and nuclear plants for the seven federal districts. Knowing only the total capacity for coal, natural gas and oil in each region, more detailed power plant data for Russia was used to split each region's capacity into fuel type, see Table A2. GeoHive (www.geohive.com) and Enipedia (http://enipedia.tudelft.nl/wiki/Main Page) have 
information about single plants with their location and capacity. This has made it possible to allocate plants to each region. However, the many multi-fuelled power plants are complicating the picture. Where power plants operate on several fuels they have been allocated according to their primary fuel type.

For hydropower, in RU2 and RU3 it is assumed that there is production of reservoir hydro only. For RU1, RusHydro's annual report for 2009 (RusHydro 2010) has information about a pumped storage power plant located in this region. The capacity of this plant has been deducted from the 2009 hydro capacity in SO (2011). Finally, the nuclear capacities in SO (2011) can be allocated directly to RU1-3.

Table A2 Generation capacity in Russian regions in the base year (2009) in GW

\begin{tabular}{lrrrr}
\hline & RU1 & RU2 & RU3 & Total \\
\hline Reservoir hydro & 15.7 & 1.8 & 25.6 & $\mathbf{4 3 . 1}$ \\
Pumped hydro & 1.3 & - & - & $\mathbf{1 . 3}$ \\
Run-of-river hydro & - & - & - & - \\
Natural gas power & 102.1 & 32.8 & 14.9 & $\mathbf{1 4 9 . 8}$ \\
Steam coal power & 15.8 & 11.1 & 30.6 & $\mathbf{5 7 . 5}$ \\
Lignite power & 1.8 & 3.5 & 12.3 & $\mathbf{1 7 . 6}$ \\
Oil power & 5.2 & 2.4 & 9.9 & $\mathbf{1 7 . 5}$ \\
Waste power & 1.6 & 0.4 & 0.4 & $\mathbf{2 . 4}$ \\
Bio power & 0.4 & 0.2 & 0.2 & $\mathbf{0 . 8}$ \\
Wind power & - & - & - & - \\
Solar power & - & - & - & - \\
Nuclear power & 21.5 & 0.6 & - & $\mathbf{2 2 . 1}$ \\
\hline
\end{tabular}

The solar power potential in the three regions is based on the same sources as for the rest of the model countries, that is, the NASA Surface Meteorology and Solar Energy database (https://eosweb.larc.nasa.gov/project/sse/sse table). Through the NASA database the best and worst locations for solar insolation were found, see Table A3.

Table A3. Solar insolation $\mathrm{kWh} / \mathrm{m}^{2} /$ year. Average radiation incident on an equator-pointed tilted surface

\begin{tabular}{lrr} 
Region & Best (angle) & Worst (angle) \\
\hline RU1 & $1521(28)$ & $917(53)$ \\
RU2 & $1359(40)$ & $1014(50)$ \\
RU3 & $1531(33)$ & $921(54)$
\end{tabular}

The wind power potential in each region was found using several sources. IEA (2003) has a map of wind resources in Russia, which was used to find the wind hours at the best site in each region. For RU1 and RU3 this was assessed to 3700 hours, which is the same as the best wind sites in Europe. For RU2 it was assessed to 3100 hours per year, see Table A4. Data for Norway adjusted by a country size 
factor was then used to find how average annual number of wind hours depend on wind power capacity (in each of the three regions).

Table A4. Wind hours at best site in Russian regions

\begin{tabular}{lr} 
Region & Best (wind hours) \\
\hline RU1 & 3700 \\
RU2 & 3100 \\
RU3 & 3100
\end{tabular}

\section{A. 2 Consumption of energy}

IEA (2011b) has national data for electricity consumption for each of the LIBEMOD sectors, whereas the Russian Electricity Systems Operator UPS publishes data on the total regional consumption, see SO (2011). APBE (2011) has consumption data for all the federal districts by sector for 2009. The totals for each sector are not quite the same, so in the present study the IEA total is used for each sector, and the consumption in the three regions is allocated based on the data from APBE (2011).

Further, IEA (2011b) also has national data for the consumption of the three coal types; steam coal, coking coal and lignite. Statistical Yearbook of Russia, see Rosstat (2010),, has data for total coal consumption in each federal region, which was used to find total coal consumption for the three Russian LIBMOD districts (RU1-3). To allocate the consumption between sectors in each region, several Russian sources were used along with some own assumptions.

For steam coal and lignite the following approach was used: APBE (2010a) has data for electricity produced in each federal district by fuel in 2009. These shares are used for the electricity producing sector for steam coal and lignite. For the household, service and transport sector population shares were applied, whereas for the industry sector consumption is set to that of the IEA data for all three regions. For coking coal there is consumption in the industry sector only. Due to no data sources for regional consumption, own assumptions have been made. Because a large share of the coking coal consumed in Russia is used in steel production, the consumption is allocated between the regions based on data on regional steel production in $\mathbf{2 0 0 9}$ from Statistical Yearbook of Russia.

APBE (2010) is used for oil consumption in electricity production for all three regions. For the transport sector regional consumption is based on an overview of consumption of gasoline and diesel fuel by federal districts for 2010, see http://solex-un.ru/energo/reviews/avtomobilnyytransport/obzor-1. The consumption in households and the service sector is allocated based on population, whereas for the industry sector it is assumed - due to lack of data - that consumption is divided 45-45-10 between RU1, RU2 and RU3; this roughly reflects the location of oil-fired power plants in Russia.

Compared to other energy sources, Russia has a very low consumption of biomass in the base year, see IEA (2011b). We have no data on how the consumption is distributed between the regions, so we assume that it is based on population for all sectors. Russia has no consumption of biofuels in the 
base year, and we have assumed that this is also the case in future years. Tables A5-A7 show consumption of energy in 2009 by Russian regions.

Table A5. Consumption of energy in the base year (2009) in RU1

\begin{tabular}{llrrrrrr}
\hline & & & \multicolumn{5}{c}{ Electricity } \\
& & Households & Industry & Transport & producers & Services & \multicolumn{1}{c}{ Total } \\
\hline Electricity & TWh & 214.1 & 346.9 & 45.5 & 2.7 & 150.4 & $\mathbf{7 5 9 . 6}$ \\
Natural gas & Mtoe & 39.8 & 41.1 & & 147.7 & 2.2 & $\mathbf{2 3 0 . 8}$ \\
Steam coal & Mtoe & 1.3 & 5.3 & & 4.6 & 1.6 & $\mathbf{1 2 . 9}$ \\
Coking coal & Mtoe & & 15.5 & & & & $\mathbf{1 5 . 5}$ \\
Lignite & Mtoe & 0.1 & 0.1 & & 3.0 & 0.0 & $\mathbf{3 . 2}$ \\
Oil & Mtoe & 3.3 & 20.4 & 44.8 & 8.9 & 1.2 & $\mathbf{7 8 . 7}$ \\
Biofuel & Mtoe & & & 0.0 & & & $\mathbf{0 . 0}$ \\
Biomass & Mtoe & 0.7 & 0.3 & & 0.7 & 0.5 & $\mathbf{2 . 1}$ \\
\hline
\end{tabular}

Table A6. Consumption of energy in the base year (2009) in RU2

\begin{tabular}{llrrrrrr}
\hline & & & \multicolumn{5}{c}{ Electricity } \\
& & Households & Industry & Transport & producers & Services & \multicolumn{1}{c}{ Total } \\
\hline Electricity & TWh & 37.5 & 127.0 & 15.0 & & 24.2 & $\mathbf{2 0 3 . 8}$ \\
Natural gas & Mtoe & 1.5 & 12.5 & & 45.5 & 0.3 & $\mathbf{5 9 . 9}$ \\
Steam coal & Mtoe & 0.2 & 5.0 & & 6.9 & 0.2 & $\mathbf{1 2 . 2}$ \\
Coking coal & Mtoe & & 11.9 & & & & $\mathbf{1 1 . 9}$ \\
Lignite & Mtoe & 0.0 & 0.1 & & 4.4 & 0.0 & $\mathbf{4 . 5}$ \\
Oil & Mtoe & 0.4 & 20.3 & 5.1 & 0.4 & 0.1 & $\mathbf{2 6 . 4}$ \\
Biofuel & Mtoe & & & 0.0 & & & $\mathbf{0 . 0}$ \\
Biomass & Mtoe & 0.1 & 0.0 & & 0.1 & 0.1 & $\mathbf{0 . 2}$ \\
\hline
\end{tabular}

Table A7. Consumption of energy in the base year (2009) in RU3

\begin{tabular}{llrrrrrr}
\hline & & & \multicolumn{5}{c}{ Electricity } \\
& & Households & Industry & Transport & producers & Services & \multicolumn{1}{c}{ Total } \\
\hline Electricity & TWh & 94.9 & 193.5 & 20.7 & & 56.8 & $\mathbf{3 6 5 . 9}$ \\
Natural gas & Mtoe & 0.3 & 7.1 & & 11.0 & 0.1 & $\mathbf{1 8 . 5}$ \\
Steam coal & Mtoe & 0.3 & 22.3 & & 27.1 & 0.4 & $\mathbf{5 0 . 1}$ \\
Coking coal & Mtoe & & 4.4 & & & & $\mathbf{4 . 4}$ \\
Lignite & Mtoe & 0.0 & 0.1 & & 17.1 & 0.1 & $\mathbf{1 7 . 2}$ \\
Oil & Mtoe & 0.8 & 4.5 & 10.9 & 2.7 & 0.3 & $\mathbf{1 9 . 2}$ \\
Biofuel & Mtoe & & & 0.0 & & & $\mathbf{0 . 0}$ \\
Biomass & Mtoe & 0.2 & 0.1 & & 0.2 & 0.1 & $\mathbf{0 . 5}$ \\
\hline
\end{tabular}




\section{A.3 Energy trade}

\section{Nodes}

Energy trade between the three Russian regions takes place in the same way as for the other model countries, i.e. only countries/regions being neighbours can trade directly. The consumption nodes are the same for all traded goods, and in addition there are production nodes for natural gas, see Figure 1. For RU1 and RU2 these nodes are situated based on current production of natural gas. Thus the distance from the production nodes to the consumption nodes corresponds fairly well with today's pipeline structure. Natural gas can be sent directly from the production node in RU2 to the consumption node in RU1.

RU3 is more problematic due to the vast distances. The current production of natural gas in RU3 is situated in the Far East on the eastern coast at Sakhalin. The gas extracted here is mainly exported as LNG. In LIBEMOD RU3s production node is situated in Eastern-Siberia by the undeveloped gas field Kovytka.

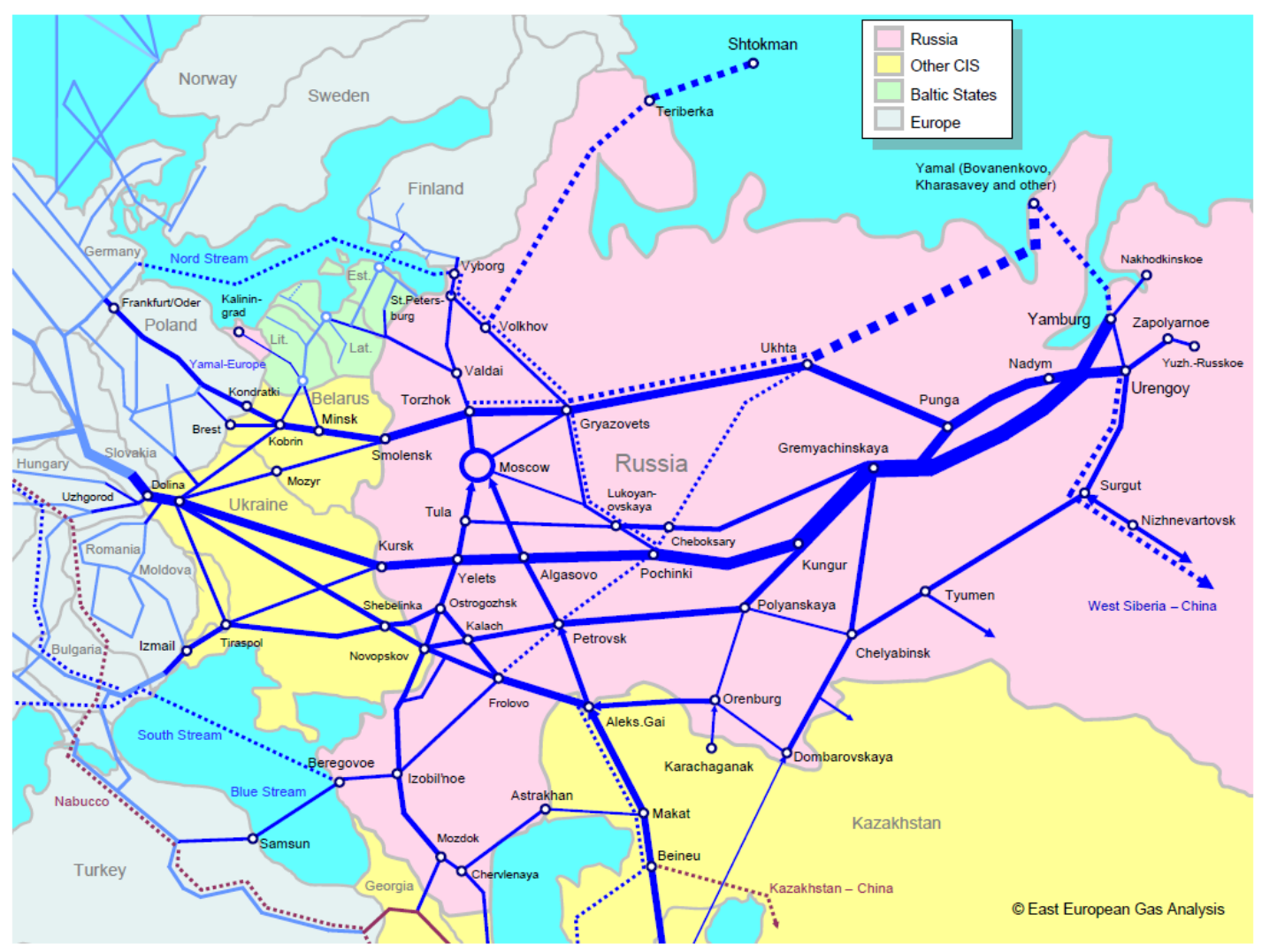

Figure A1. Map of the natural gas pipelines of Russia

Source: East European Gas Analysis. http://www.eegas.com/fsu.htm

\section{Nodes}

IEA Natural Gas Statistics (http://www.oecd-ilibrary.org/energy/data/iea-natural-gas-informationstatistics naturgas-data-en) gives information about the trade flows from Russia (national figures) to Europe and the rest of the world. In LIBEMOD it is assumed that all the gas that is imported to Europe goes through RU1 as this is consistent with the pipeline structure towards Europe. 
Table 10 shows international transmission capacities for natural gas in 2009 - the gas pipeline system within Russia and towards Europe is shown in Figure A1. The capacity between RU2 and RU1 is assumed to be larger than the export capacity to Europe as the pipelines are also used for domestic transport of gas. For the same reason some capacity is also added between RU2 and RU3 (from Surgut and Tyumen into Western Siberia). It is also assumed that RU3 has some capacity towards non-European countries (Rest Of World): currently this is - according to data from ENTSOG (http://www.entsog.eu/maps/transmission-capacity-map) - the case for gas fields in the eastern parts of the Far East.

The Federal Tariff Service provides a set of regulated tariffs that the distributors pay Gazprom for the gas in all the 83 regions. The differences in the regulated tariffs, corrected by the distance to the gas fields, are in line with World Energy Outlook 2010, see IEA (2010), which provides information on costs for international transportation of gas (toe $/ 100 \mathrm{~km}$ ). Based on this it is assumed that the same transportation costs apply between the Russian regions as for the rest of the model countries.

\section{Electricity}

Abdurofikov (2009) provides transmission capacities for electricity between 28 zones within Russia. These zones have been aggregated to the three Russian LIBEMOD regions. Further, SO (2011) has a table showing transmission of electricity between the seven Russian federal districts (SO 2011). This data has been aggregated to fit the LIBEMOD-regions.

\section{A.4 Prices and Taxes}

APPE (2011) has a set of electricity prices by (eight) consumer group for each of the (seven) federal districts in 2009. The prices for each of the three model regions have been found by taking the weighted average of the prices in the relevant federal districts.

IEA Energy Prices and Taxes (IEA 2011c) has national prices for steam coal and coking coal to industry. APPE (2008) has forecast prices for 2009 for coal from different coal fields in the federal districts. This is used to create a regional dataset of prices of steam coal and coking coal to industry and electricity production. For the household sector, the industry price with an added distribution cost has been used for each region. For lignite we rely on the same source using the price of coal from coal fields known to extract lignite.

IEA (2011c) has a national "heavy fuel oil" price for industry. "Scenario Conditions of Electricity in the Russian Federation from 2009-2020" has forecast prices for oil (to electricity producers) for 2009 for each of the Russian federal districts. The variation in the forecast prices has been used to adjust the IEA price for each LIBEMOD region. For households the regionalised industry prices were used with an added distribution cost. For oil in the transport sector, IEA (2011c) has national prices for unleaded premium and automotive diesel. These along with daily prices of petrol in the 83 Russian regions were used to get a LIBEMOD dataset on oil.

Biomass prices are based on wood pellets prices from Rakitova et al. (2009). This report has some pellets prices for $\mathbf{2 0 0 9}$ for residential and industrial consumers. A dataset with prices for the three LIBEMOD regions for all sectors has been created based on this source and own assumptions. User prices by Russian districts are shown in Tables A8-A10. 
Table A8. User prices in RU1 in 2009.

\begin{tabular}{llrrrrr}
\hline & & & & \multicolumn{3}{c}{ Electricity } \\
& & Households & Industry & Transport & producers & Services \\
\hline Electricity & $€_{2009} /$ TWh & 37 & 37 & 37 & - & 58 \\
Gas & $€_{2009} /$ toe & 60 & 84 & - & 84 & 84 \\
Steam coal & $€_{2009} /$ toe & 255 & 72 & - & 72 & 255 \\
Coking & & & & & & \\
coal & $\epsilon_{2009} /$ toe & - & 146 & - & 146 & - \\
Lignite & $€_{2009} /$ toe & 239 & 58 & - & 58 & 239 \\
Oil & $€_{2009} /$ toe & 443 & 212 & 423 & 212 & 443 \\
Biofuel & $€_{2009} /$ toe & - & - & 1289 & - & - \\
Biomass & $€_{2009} /$ toe & 1232 & 296 & - & 296 & 1232 \\
\hline
\end{tabular}

Table A9. User prices in RU2 in 2009.

\begin{tabular}{llrrrrr}
\hline & & & \multicolumn{5}{c}{ Electricity } \\
& & Households & Industry & Transport & producers & Services \\
\hline Electricity & $€_{2009} /$ TWh & 27 & 40 & 40 & - & 59 \\
Gas & $€_{2009} /$ toe & 52 & 65 & - & 65 & 65 \\
Steam coal & $€_{2009} /$ toe & 225 & 46 & - & 46 & 225 \\
Coking & & & & & & \\
coal & $€_{2009} /$ toe & - & 123 & - & 123 & - \\
Lignite & $€_{2009} /$ toe & 221 & 43 & - & 43 & 221 \\
Oil & $€_{2009} /$ toe & 425 & 196 & 449 & 196 & 425 \\
Biofuel & $€_{2009} /$ toe & - & - & 1289 & - & - \\
Biomass & $€_{2009} /$ toe & 718 & 172 & - & 172 & 718 \\
\hline
\end{tabular}

Table A10. User prices in RU3 in 2009.

\begin{tabular}{llrrrrr}
\hline & & & & \multicolumn{3}{c}{ Electricity } \\
& & Households & Industry & Transport & producers & Services \\
\hline Electricity & $€_{2009} /$ TWh & 28 & 28 & 28 & - & 46 \\
Gas & $€_{2009} /$ toe & 64 & 60 & - & 60 & 60 \\
Steam coal & $€_{2009} /$ toe & 236 & 56 & - & 56 & 236 \\
Coking & & & & & & \\
coal & $€_{2009} /$ toe & - & 116 & - & 116 & - \\
Lignite & $€_{2009} /$ toe & 215 & 38 & - & 38 & 215 \\
Oil & $€_{2009} /$ toe & 447 & 216 & 470 & 216 & 447 \\
Biofuel & $€_{2009} /$ toe & - & - & 1289 & - & - \\
Biomass & $€_{2009} /$ toe & 718 & 172 & - & 172 & 718 \\
\hline
\end{tabular}

